\title{
Archaeometric Studies on the Characterization and Deteriorations of Glass Artifacts of Su Terazisi and Kral Kızı Regions in Enez (Ainos) Excavation*
}

\author{
Enez (Ainos) Kazısı Su Terazisi ve Kral Kızı Bölgelerinden Ele Geçen Camların \\ Karakterizasyonu ve Bozulmaları Üzerine Arkeometrik Çalışmalar
}

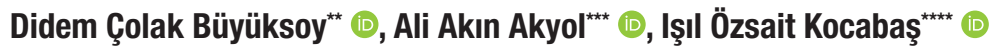

\begin{abstract}
Archaeometric investigations were carried out to determine and correlate the chemical contents with the layers of deterioration of the 19 glass finds dating to the Roman Period uncovered from Su Terazisi and Kral Kızı Regions of Enez (Ainos) ancient city. The physical condition of glass finds was firstly examined, the layers of deterioration on the glass surface were documented with photographs, their thickness was measured with a digital thickness meter, their colors were identified by a chromameter, and images of the bubbles and deterioration products were taken under an optical microscope. When the deterioration layers of the samples belonging to the Roman Period were examined visually and with an optical microscope, the types of deterioration resulting from the chemical composition of the glass, such as iridescence, dulling, black discoloration and pitting were identified. A table was created of the existing degree of deterioration. Micro-XRF and Polarized Energy Dispersive-X-Ray Fluorescence (PED-XRF), Scanning Electron MicroscopeEnergy Dispersive Spectrometry (SEM-EDS), and Raman (Confocal) Spectroscopy methods were used to determine the element and mineralogical contents, and the deterioration layer of the glass samples. When all the archaeometric results were evaluated, it was revealed that there was a difference between the bulk glass and the deterioration layers.
\end{abstract}

\section{Keywords}

Archaeological Glass Chemistry, Archaeological Glass Deteriorations, PED-XRF, SEM-EDS, Raman Spectroscopy

* This paper was produced from the master's thesis titled "Archaeometric Studies on the Deteriorations of Glass Artefacts of Su Terazisi and Kral Kizi Regions in Enez (Ainos) Excavation" prepared by Didem Çolak-Büyüksoy and supervised by Assoc. Prof. Dr Işı Özsait-Kocabaş and Assoc. Prof. Dr Ali Akın Akyol at Istanbul University, Institute of Social Sciences, Department of Conservation and Restoration of Cultural Property.

** Correspondence to: Didem Çolak-Büyüksoy (Research Asst.), Yildiz Technical University, Faculty of Architecture, Department of Conservation and Restoration of Cultural Property, Istanbul, Turkey. E-mail: colak.didem@gmail.com, ORCID: 0000-0001-5814-4523

*** Ali Akın Akyol (Assoc. Prof. Dr.), Haci Bayram Veli University, Faculty of Fine Art, Department of Conservation and Restoration of Cultural Property, Ankara, Turkey. E-mail: aliakinakyol@gmail.com, ORCID: 0000-0002-4174-575X

**** Işıl Özsait-Kocabaş (Assoc. Prof. Dr.), Istanbul University, Faculty of Letters, Department of Conservation and Restoration of Cultural Property, Istanbul, Turkey. E-mail: isilozsait@gmail.com, ORCID: 0000-0002-1926-0764

To cite this article: Colak-Buyuksoy, Didem, Akyol, Ali Akin and Ozsait-Kocabas, Isil. "Archaeometric Studies on the Characterization and Deteriorations of Glass Artifacts of Su Terazisi and Kral Kızı Regions in Enez (Ainos) Excavation." Art-Sanat, 16(2021): 87-122. https://doi.org/10.26650/artsanat.2021.16.0004 


\section{Öz}

Bu çalışmada Enez (Ainos) Kazısı Su Terazisi ve Kral Kızı bölgelerinden ele geçen 19 adet etütlük cam buluntunun kimyasal içeriğinin belirlenmesi ve kimyasal içeriklerinin örneklerde görülen bozulma tabakaları ile ilişkilendirilmesi için arkeometrik incelemeler yapılmıştır. Cam buluntuların öncelikle fiziksel durumları incelenmiş, cam yüzeyinde bulunan bozulma tabakaları fotoğrafla belgelenmiş, dijital kalınlık ölçer ile kalınlıkları ölçülmüş, renk ölçümleri yapılmış ve optik mikroskop altında habbe ve bozulma ürünlerinin görüntüleri çekilerek belgelenmiştir. Roma Dönemi’ne ait etütlük örneklerin bozulma tabakaları görsel olarak ve optik mikroskop ile incelendiğinde; sedef oluşumu, matlaşma, siyah kabuk oluşumu ve çukur oluşumu gibi camın kimyasal bileşiminden kaynaklanan bozulma türleri tespit edilmiştir. Camın yüzeyinde mevcut olan bozulmalar derecelendirilerek bir tablo oluşturulmuştur. Cam örneklerin bozulma tabakalarını, element ve mineralojik içeriklerini belirlemek için Mikro-XRF, Polarize Enerji Dağılımlı X-Işını Floresans (Polarized Energy DispersivePED-XRF), Taramalı Elektron Mikroskobu- Enerji Dağılımlı Spektrometresi (Scanning Electron Microscope-Energy Dispersive Spectrometry, SEM-EDS) ve Raman (Konfokal) Spektroskopi yöntemleri kullanılmıştır. Tüm arkeometrik sonuçlar değerlendirildiğinde, bulk cam ve bozulma tabakaları arasında farklılık olduğu ortaya koyulmuştur.

\section{Anahtar Kelimeler}

Arkeolojik Cam Kimyası, Arkeolojik Cam Bozulmaları, PED-XRF, SEM-EDS, Raman Spektroskopi

\section{$\underline{\text { Genisletilmis Özet }}$}

Camların zaman içerisinde su ve/veya neme maruz kalması cam objelerin bozulmasına neden olmaktadır. Ancak camın içeriği, camın bulunduğu ortam $(\mathrm{pH}$, sıcaklık ve nem) ve firın sıcaklığı, firında kalma süresi gibi etkenler de camın bozulmasını etkileyen faktörlerdir. Aynı ortam koşullarına sahip olan cam objelerde cam içeriklerinin farklı olması nedeniyle farklı bozulma türleri meydana gelebilmektedir. Bu çalışmanın amacı Enez Kazısı Su Terazisi ve Kral Kızı bölgelerinden ele geçen camların kimyasal içeriklerinin ve bozulma sürecinde meydana gelen kimyasal değişikliklerin araştırılması ve sonuçların bu konudaki çalışmalara katkı sağlamasıdır. Camın bozulma tabakalarının incelenmesi camın konservasyon yöntemlerinin geliştirilmesinde de yararlı olabilmektedir.

Enez (Ainos) Kazısı Su Terazisi ve Kral Kızı bölgelerinden ele geçen Roma Dönemi'ne tarihlenen 19 adet etütlük cam buluntunun kimyasal içeriğinin belirlenmesi ve kimyasal içeriklerinin örneklerde görülen bozulma tabakaları ile ilişkilendirilmesi için arkeometrik incelemeler yapılmıştır. Cam buluntuların öncelikle detaylı belgeleme çalışmaları (fotoğraflama, kalınlık ölçümü, renk ölçümü, optik mikroskop altında habbe ve bozulma ürünlerini görüntüleme) yapılmıştır. Camın yüzeyinde mevcut olan bozulmaların görsel olarak incelemesi yapılmış; var olan bozulma türleri ve bozulma dereceleri belirlenerek bir tablo oluşturulmuştur. Cam örneklerin element ve mineralojik içeriklerini belirlemek ve bozulma tabakalarını analiz etmek için X-Işını Floresans (Polarize Enerji Dağılımlı XRF (PED-XRF) ve Mikro-XRF), Taramalı Elektron Mikroskobu- Enerji Dağılımlı Spektrometresi (Scanning Electron Microscope-Energy Dispersive Spectrometry, SEM-EDS) ve Raman (Konfokal) Spektroskopi yöntemleri kullanılmıştır. Analiz sonuçlarına göre sodyum-kalsiyumsilisyum içerikleri değerlendirildiğinde camların tipik soda-kireç-silis camı olduğu tespit edilmiştir. Potasyum ve magnezyum içeriklerinin düşük olması bitki külü yerine 
natronun ergitici olarak kullanıldığını göstermektedir. Örneklerin stronsiyum ( $\mathrm{Sr}$ ) ve zirkonyum (Zr) içerikleri, üretimde silis kaynağ1 olarak deniz kumu kullanıldığını düşündürmektedir. Örneklerin renk ölçümü (kromametrik analiz) ile görünen renkleri belirlenmiş ve bu sonuçlar daha sonra PED-XRF analizi ile desteklenmiştir. Cama renk verici elementler; demir $(\mathrm{Fe})$, bakır $(\mathrm{Cu})$, kobalt $(\mathrm{Co})$ ve kurşun $(\mathrm{Pb})$ olarak belirlenmiştir. Renk ölçümünde rengi mavimsi-yeşil olarak belirlenen EET-G1 örneğinde ayrıca bu sonucu destekleyebilecek Mısır mavisi, bileşimi kalsiyum bakır silikat (Ca$\mathrm{CuSi}_{4} \mathrm{O}_{10}$ cuprorivaite) olan pigment $381-1068 \mathrm{~cm}^{-1}$ doruk noktaları arasında Raman analizi ile de tespit edilmiştir.

Camın üretim teknolojisi hakkında bilgi veren habbeler yani cam hamuru içerisinde hapsolan hava boşlukları başlangıçta daireselken yapım teknikleri ile habbelerin şekilleri değişiklik göstermektedir. Antik dönemde camlar, kalıp ya da üfleme teknikleri (serbest üfleme ve kalıba üfleme) kullanılarak üretilmekteydi. Kalıp ya da üfleme işlemleri sırasında, cam hamurunda bulunan habbeler daireselken, gittikçe uzayan elips şekilleri alabilmektedir. Serbest üfleme tekniğinde, habbeler merkezden dışa doğru gittikçe uzamaktadır. İncelenen örneklerin genel olarak dairesele yakın ve iri olan habbe formlarına bakarak ve literatürdeki diğer çalışmalar ile karşılaştırılması yapılarak Enez camlarının serbest üfleme tekniğinde üretildiği söylenebilir.

Roma Dönemi'ne ait etütlük örneklerin bozulma tabakaları görsel olarak ve optik mikroskop ile incelendiğinde sedef oluşumu, matlaşma, siyah kabuk oluşumu ve çukur oluşumu gibi camın kimyasal bileşiminden kaynaklanan bozulma türleri tespit edilmiştir. Örneklerde görülen bozulmaların yoğunluğunu belirtmek için kendi içlerinde kıyaslayarak bir derecelendirme tablosu oluşturulmuştur. En yoğun bozulma seviyeleri sedef oluşumu ve siyah kabuk oluşumu bozulma türlerinde görülmektedir. Cam harmanında ağ yapıcı olarak bulunan $\mathrm{SiO}_{2}$ 'nin yüksek miktarda olması camın mekanik direncini arttırmaktadır. Enez cam örneklerinde beklenenden düşük olan $\mathrm{SiO}_{2}$ içeriğinin nedeni camlarda görülen bozulmalardır. Camın yapısında bulunan, ergitici olarak cam harmanına eklenen sodyum $\left(\mathrm{Na}_{2} \mathrm{O}\right)$ ve potasyum $\left(\mathrm{K}_{2} \mathrm{O}\right)$ iyonları ortamda su ve nem bulunması durumunda, su ve nemdeki hidrojen iyonları ile yer değiştirerek sodyum veya potasyum hidroksitleri oluşmaktadır. Bununla birlikte, camın elektriksel nötrlüğünün korunması için, sudaki hidronyum iyonlarının $\left(\mathrm{H}_{3} \mathrm{O}^{+}\right)$bünyesindeki pozitif yüklü hidrojen iyonları, cam ağından kimyasal olarak çözünen alkali iyonları ile yer değiştirir. Bu işlem bazen bir jel tabakası olarak adlandırılan bir tabakanın oluşmasına neden olur. Başlangıçta cam yüzeyinde oluşan jel tabakası, silisyum açısından zengin, sodyum ve kalsiyum açısından fakirdir. Bozulma tabakalarında $\mathrm{SiO}_{2}$ içeriğinin fazla olmas1, camlarda görülen bozulmaları destekler niteliktedir. Cam objelerin nem ve/ veya su ile temas etmesi sonucu yüzeyde oluşan jel tabakasında ergitici $\left(\mathrm{Na}_{2} \mathrm{O}\right)$ ve sağlamlaştırıcı $(\mathrm{CaO})$ miktarının azalması beklenmektedir. Ancak örneklerin SEM-EDS analizi sonuçlarında $\mathrm{Na}_{2} \mathrm{O}$ ve $\mathrm{CaO}$ miktarının yüksek olmasının, antik kentin denize 
çok yakın bir konumda olması nedeniyle denizel etki sonucu oluşan birikintilerden kaynaklı olduğu düşünülmektedir. Siyah kabuk oluşumu tabakası, mangan içeriği ile karakterizedir. Yüksek mangan içeriği ile birlikte demir içeriğinin de yüksek olması beklenmektedir. Siyah kabuk oluşumunda, yüksek mangan içeriği görülürken, aynı element camın genel yapısında ve diğer bozulma türlerinde her zaman daha az bulunmaktadır. Cam örneklerin Mikro XRF, PED-XRF ve SEM-EDS analizleri sonucunda siyah kabuklanma türü bozulma ürünlerinde mangan ve demir öne çıarken, Raman analizi ile saptanan mangan ve demir içeriklerinin varlığı bu sonuçları desteklemektedir. Raman analizi sonucunda, jel tabakasında $\mathrm{SiO}_{2}$ ve Fe içeriğinin ve siyah kabuk oluşumunda görülen tabakalarda mangan ve demir içeriğinin yanı sıra mavimsi-yeşil renkteki örneğin rengini destekleyebilecek pigment içeriği ortaya çıarılmıştır.

Arkeometrik yöntemler ile camın yapısal özelliklerinin kimyasal analizleri yapılarak camların ham maddesi, çeşitliliği, ticareti, üretim yerleri ve bozulmaları hakkında bilgiler edinilebilmektedir. Cam objelerin bozulmaları üzerine yapılan çalışmaların azlığının yanı sıra, camın ham maddesi ve çeşitliliği üzerine yapılan çalışmalar da oldukça sınırlıdır. Aynı döneme ait Levant ve Mısır camları çok iyi araştırılmışken, Anadolu camları ile bağlantıları kurulamamıştır. Çünkü Türkiye'deki arkeolojik kazılardaki işlikler, arkeolojik buluntular ve arkeometrik çalışmalar henüz bu konuya tam olarak hizmet edememektedir. Cam bozulmalarının kimyasal süreçleri kapsamlı bir şekilde incelenmiş olsa da kısmen cam hamurunun bileşiminden ve imalatından camın gömülü olduğu toprağa kadar dikkate alınması gereken çok sayıda faktör nedeniyle henüz tam olarak anlaşılamamıştır. Bu çalışma, arkeolojik kazılarda toprak altından çıkan cam objelerin bozulmuş yüzeyleri ile örneklerde meydana gelen bileşimsel değişiklikler arasındaki korelasyonu ele almaktadır. 


\section{Introduction}

Since the studies on glass production and technology in Anatolia are quite limited, our knowledge about raw material, production and production centers is also limited. Since most of the glass findings have been examined in terms of art history and archeology in the studies up to now, the number of studies that we can obtain information about the production technology, raw material resources and chemical content of glass has remained limited. ${ }^{1}$ In this study, the chemical components of glass samples obtained from the Enez excavation were determined. In addition, archaeometric studies are evaluated on the deterioration of the chemical structure of the glass due to the exposure of the glass to moisture/water.

The ancient city of Ainos is located $180 \mathrm{~km}$ from the city of Enez, Turkey. Located to the west and north-west of this city is Greece, to the north is İpsala and to the south and south-west of this city is the Aegean Sea. Enez is first mentioned in the ancient sources as a Thracian city named Ainos in Homer's Iliad. ${ }^{2}$ Enez has been an important residential area throughout history due to hosting developing societies since the Neolithic Age, being located at the intersection of land and sea routes connecting the Balkans with the Aegean world and being in Anatolia with its fertile lowland, wide hinterland like the Ergene Basin and with the presence of the Maritsa. ${ }^{3}$ Archaeological excavations and researches carried out at the Ainos archaeological site and Hoca Cesme Tell have shown that the first settlement in the region began in the Neolithic Age $(\sim 6,500 \mathrm{BC})$ and continued in the Chalcolithic, Bronze, Iron, Classical Ages, Roman, Byzantine and Ottoman periods. ${ }^{4}$

This study covers the archaeometric studies of the glass artifacts recovered from $\mathrm{Su}$ Terazisi and Kral Kizi regions of the Enez excavation. ${ }^{5}$ The tombs at the Su Terazisi Necropolis, located at the entrance of Enez, the oldest necropolis of Ainos, consist of mostly three; in rare occasions, four imbricated layers. In the necropolis area, generally there are sarcophagus, tile, cist grave, urn and simple soil type tombs. While the

1 Ömür Bakırer, "Cam Buluntuların Değerlendirilmesinde Arkeometrik Araştırmaların Önemi," I. Arkeometri Toplantısı Bildiriler Kitabı (Ankara: Kültür ve Turizm Bakanlığı Yayınları, 1985), 61; Ali Akın Akyol and Yusuf Kağan Kadığlu, “Tekfur Sarayı Cam Buluntuları Arkeometrik Çalışmaları,” Türkiye Bilimler Akademisi Kültür Envanteri Dergisi 13 (2015), 29.

2 Afif Erzen, “Enez Kazıları,” XI. Türk Tarih Kongresi'nden Ayrtbasım (Ankara: Türk Tarih Kurumu, 1994), 301; Sait Başaran, "Enez (Ainos) Kazılar1," Türkiye Arkeolojisi ve İstanbul Üniversitesi (1932-1999) Kitabl (Ankara: İstanbul Üniversitesi Yayınları, 2000), 251.

3 Sait Başaran, "Ortaçağ'da Enez (Ainos)", Sanat Tarihi Dergisi IX (1998), 1.

4 Sait Başaran, "Enez, Ainos, Enoz”, Enez: Doğal, Kültürel ve Turistik Güzellikleri (2013), 11, 13; Başaran, "Enez (Ainos) Kazıları," 251.

5 The archaeological excavations in Enez (Ainos) ancient city were initiated in 1971-1972 and 1978-1993 by Prof. Dr. Afif Erzen. The archaeological excavations were continued by Prof. Dr. Sait Başaran in 1994-2019 (Başaran, "Enez, Ainos, Enoz," 12). It has been approved by the Ministry of Culture and Tourism that the excavation will be carried out by Assist. Prof. Dr. Gülnur Kurap as of 2021. The Ainos Archeology Excavation was carried out with the permission and material and moral support of the Ministry of Culture and Tourism, Directorate General of Cultural Assets and Museums. 
number of tombs belonging to the Byzantine and Roman Periods is quite less compared to others, there are Hellenistic, Classical and in small numbers, Archaic Period tombs present. ${ }^{6}$ Considering the glass bottle, glass bead, glass ring and ring stones found in the $\mathrm{Su}$ Terazisi necropolis area, we can say that there are a significant number of glass artifact findings. ${ }^{7}$ Kral K1z1 Basilica is a basilica with three apses and five naves, located in the southeastern part of Enez, on the western side of Taşaltı Lake, in a place which is known today as Kral Kızı. Under the apse of the basilica, remainders of a building thought to be from the Roman Period were found; however, the plan of this building was not completely understood. Tombs belonging to the Roman Period were found around the basilica and Roman Period terracotta oil lamps and glass goblets were found inside the basilica. ${ }^{8}$

\section{Methods and Analyses}

On the 19-piece study collection glass samples (F. 1, T. 1) from the Enez archaeological excavation from Su Terazisi and Kral K1zı excavation areas, which are dated back to the Roman Period and which consist of rim, base, handle and various fragments of a vessel, studies were carried out using archaeometric methods, to determine the elemental contents of the glass artifacts and to correlate existing deteriorations to their elemental contents. The abbreviation ST represents Su Terazisi, while the abbreviation KK represents Kral K1z1 in Table 1. First, the documentation of the samples was begun. The thicknesses of the glass samples were determined with a digital thickness meter.

The environment in which the glass samples are recovered is effective in the deterioration mechanism of the glass. The ancient city of Enez is located $5 \mathrm{~km}$ inland from the sea today. Although the environmental conditions are unknown, when the deterioration layers on the samples were examined, it is thought that the samples had been recovered from humid environmental conditions. ${ }^{9}$ However, the fact that the deterioration layers are not too thick indicates that the samples were not exposed to too much moisture.

6 Başaran, "Enez, Ainos, Enoz," 70-79.

7 Sait Başaran and Gülnur Kurap, "Enez (Ainos) 2011 Yılı Arkeoloji Kazısı,” 34. Kazı Sonuçları Toplantısı, vol. 2 (Ankara: Kültür Bakanlığı Yayınları, 2013), 376-378.

8 Sait Başaran and Gülnur Kurap, "Enez (Ainos) 2012 Yılı Kazı Çalışmaları ile İlgili Rapor,” 35. Kazı Sonuçları Toplantısı 3 (Ankara: Kültür Bakanlığı Yayınları, 2014), 252-253; Başaran, "Enez, Ainos, Enoz," 59-60.

9 Sait Başaran et al., "Enez (Ainos) 2008 Yılı Kazısı, Onarım-Koruma Çalışmaları,” 31. Kazı Sonuçları Toplantısı, vol 2 (Ankara: Kültür Bakanlığı Yayınları, 2010), 128. 

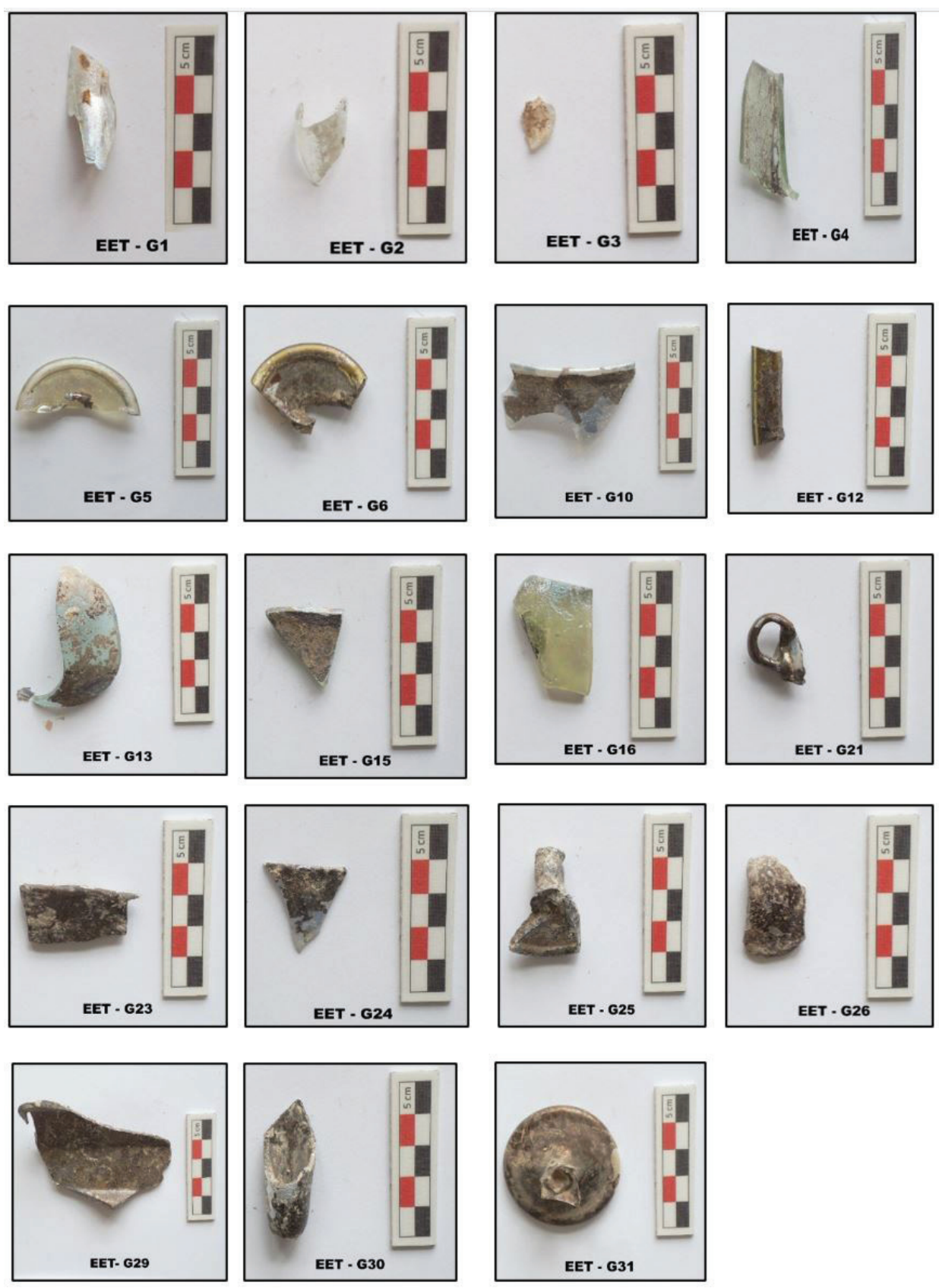

F. 1: Enez Excavation glass samples (D. Çolak Büyüksoy, 2018) 
Table 1: Descriptions, color codes (CIE L*a*b*) and thickness of Enez glass samples (D. Çolak -Büyüksoy, 2019)

\begin{tabular}{|c|c|c|c|c|c|c|c|}
\hline Sample & Description & $\begin{array}{c}\text { Year / } \\
\text { Location }\end{array}$ & $\begin{array}{l}\text { Thickness } \\
\text { (mm) }\end{array}$ & $\mathbf{L}$ & $\mathbf{a}$ & b & Color \\
\hline EET-G1 & Rim fragment & E-10/ ST-10 & 3.39 & 81.12 & -4.71 & 2.29 & Bluish green \\
\hline EET-G2 & Rim fragment & E-10/ST-11 & 4.51 & 67.06 & -7.84 & 7.23 & Bluish green \\
\hline EET-G3 & Rim fragment & E-14/ ST-38 & 4.87 & 65.57 & 0.68 & 13.08 & Whitish \\
\hline EET-G4 & Rim fragment & - & 3.25 & 44.80 & -9.38 & 10.66 & Green \\
\hline EET-G5 & $\begin{array}{l}\text { Pedestal } \\
\text { fragment }\end{array}$ & E-08/ ST-1 & 3.72 & 51.53 & -0.11 & 14.00 & Light green \\
\hline EET-G6 & $\begin{array}{l}\text { Pedestal } \\
\text { fragment }\end{array}$ & E- 09/ ST-4 & 3.40 & 43.79 & 2.92 & 16.11 & Yellowish green \\
\hline EET-G10 & Rim fragment & E- 16-ST-41 & 3.20 & 60.42 & -1.14 & 4.36 & White \\
\hline EET-G12 & Rim fragment & E-11/ST-13 & 6.77 & 36.57 & -1.64 & 16.20 & Green \\
\hline EET-G13 & Amorphous & - & 2.20 & 64.51 & -4.65 & -0.43 & Bluish green \\
\hline EET-G15 & Amorphous & E-09/ ST-4 & 3.12 & 58.11 & -5.71 & 11.77 & Light green \\
\hline EET-G16 & Amorphous & E-08/ ST-1 & 5.42 & 53.70 & -3.11 & 16.44 & Light green \\
\hline EET-G21 & Handle & E-17/KK & 3.17 & 34.37 & -1.76 & 13.12 & Green \\
\hline EET-G23 & Rim fragment & E-17/ KK & 4.50 & 25.84 & 1.83 & 4.81 & Brown* \\
\hline EET-G24 & Rim fragment & E-17/ KK & 0.90 & 50.23 & -2.56 & -2.13 & Light blue \\
\hline EET-G25 & Lid fragment (?) & E-17/ KK & 3.55 & 39.33 & -2.78 & 0.33 & Dark grey* \\
\hline EET-G26 & Amorphous & E-17/ KK & 4.05 & 22.61 & 3.25 & 7.52 & Dark brown * \\
\hline EET-G29 & Amorphous & E-17/ KK & 3.63 & 49.56 & 5.45 & 12.48 & Brown* \\
\hline EET-G30 & Base fragment & E-17/ KK & 2.28 & 31.34 & -0.85 & 2.38 & Brown* \\
\hline EET-G31 & Pedestal & E-17/ KK & 5.38 & 62.86 & -3.01 & 11.31 & $\begin{array}{l}\text { Light brown/ } \\
\text { Green }\end{array}$ \\
\hline
\end{tabular}

*Deterioration layer

Color measurement (chromametric analysis) was carried out to determine the color of the glass samples. Color measurement was made using the standard CIE L*a*b* (Commission Internationale de L 'Eclairage) color system. In this system, the "L" value that varies between 0 and 100 (white: 100, black: 0) shows the lightness/darkness value of the color. The " $+\mathrm{a}$ " value (between 0 and +60 ) indicates the red intensity, the "-a" value (between 0 and -60) indicates the green intensity, the " $+\mathrm{b}$ " value (between 0 and +60 ) indicates the yellow intensity and the "-b" value (between 0 and -60 ) indicates the blue intensity. In color measurement, a portable Chromameter with a ColorQA Pro System III program was used.

In order to determine the production techniques of glass samples, deterioration products as well as bubbles were examined with an optical microscope.

For analysis, samples with intense and different types of deterioration layers were selected and visual identification of the deteriorations on the samples were made, con- 
sidering the degree of deterioration, from 0 to 4 a table was created by grading them as "0: None; 1: Very light; 2: Light; 3: Heavy; 4: Very heavy" (T. 4). " 0 " indicated that the sample graded as such had no deterioration, and "4" indicated that the sample graded as such had very intense deterioration.

$\mathrm{X}$-Ray Fluorescence (PED-XRF and Micro-XRF) analysis of the samples was performed. With an X-LAB 2000 model device, PED-XRF analysis was carried out on 10 samples, which allowed analysis in terms of quantity. PED-XRF is a destructive analysis method, but an informative technique. For analysis, at least $1.5-2 \mathrm{~g}$ of sample is pulverized and mixed with resin. These samples were selected from among the samples suitable for this analysis. Other samples were analyzed by SEM-EDS analysis. In the preparation phase ahead of the analysis, glass samples weighing 2-3 grams were pulverized in an agate mortar and $32 \mathrm{~mm}$ disc pellets were formed. Samples were mixed with resin to be able to use on the device and were prepared for analysis. In the analysis, USGS (United States Geological Survey) standards were used and GEOL, GBW-7109 and GBW-7309 were referenced. Elements with the atomic numbers from $11(\mathrm{Na})$ to $92(\mathrm{U})$ can be analyzed with the X-LAB 2000 model PED-XRF spectrometer. In the analysis results, approximately 50 elements were determined as major, minor and trace elements; major and minor elements were denoted as $\%$ and trace elements were denoted as ppm (parts per million). The sensitivity limit of the device was $0.5 \mathrm{ppm}$ for heavy elements and $10 \mathrm{ppm}$ for light elements. PED-XRF analysis allowed the determination of all chemical components characterizing the examined glass samples, except for boron, lithium and fluorine which were lost due to weight loss at high temperatures $\left(950^{\circ} \mathrm{C}\right)$. Furthermore, Micro-XRF analysis was performed on two samples that had two different deterioration types with a Spectro Midex device, which allows direct application.

Scanning electron microscopy (SEM) was used to examine the samples and elemental analysis was carried out with an Energy Dispersive X-ray spectrometer (EDS) connected to SEM. In this study, a TESCAN EasySEM scanning electron microscope that is compatible with a Bruker X-Flash 410-M detector (Software: Esprit 1.9) was used. Samples were coated with carbon to obtain high-resolution images, which does not affect the analysis result; the images were taken by using secondary (SE) and backscattered (BSE) detectors. All carbon element findings were neglected in the analysis results to ensure the carbon coating does not affect the results.

Minerals and compounds that make up the composition of glass samples were determined with the Confocal Raman spectroscopy analysis method. Raman measurements were performed with a Thermo DXR spectrometer. The system was equipped with a $633 \mathrm{~nm}$ laser, an electrical cooled charge coupled device (CCD) detector, an 
Olympus optical microscope with 10X, 20X, 50X and 100X long focus objectives. Instrument's calibration was tested by using a polystyrene film. Raman spectra were taken at a resolution of $2 \mathrm{~cm}^{-1}$ between $100-2800 \mathrm{~cm}^{-1}$ and 100-1200 $\mathrm{cm}^{-1}$. Raman spectra were evaluated by the Labspec 4.02 program. Raman spectra and Raman images can be obtained swiftly with the confocal spectrometer. Raman spectra were obtained on some selected glass samples. Peaks which were showing bending vibration $\left(500 \mathrm{~cm}^{-1}\right)$ and stretching vibration $\left(1100 \mathrm{~cm}^{-1}\right)$ movements related to Si-O vibration at the energy levels of 500 and $1100 \mathrm{~cm}^{-1}$ respectively were determined.

\section{Results and Assessments}

\section{Chemical Composition of Glasses}

Comparing the color measurement results with the colors determined by visual examination, it can be determined that there is symmetry between the results. L values range from 81.12 to 22.61 ; values for $( \pm \mathrm{a})$ range from -9.38 to $5.45 ;( \pm \mathrm{b})$ values range from -2.13 to 16.44 (T. 1).

The bubbles that provide information about the production technology of the glass, i.e. the air trapped in the glass during the making process, both reduce the mechanical endurance of the glass and cause optical image defects. It was determined by the studies that antimony $\left(\mathrm{Sb}_{2} \mathrm{O}_{3}\right)$ oxide was used in ancient times for the process of refining (fining) in order to eliminate air gaps as used today. In ancient times, glass vessels were produced by using molds or blowing techniques. While the bubbles found in the glass are circular in the beginning, the shapes of them change with the production techniques. It is possible to see longer elliptical bubble shapes in the vessels made with the blowing technique. In the free-blowing, the bubbles get longer from the center outwards. In the microscope examinations of the glasses found in Tekfur Palace, it was seen that the bubbles have a large and wide circular form like the samples examined in this study and it had been stated that these samples were produced by the free-blowing technique. The images obtained by examining the glass samples of Enez excavation under the optical microscope (for the samples; EET-G1, EET-G10, EET-G13, EET-G21, EET-G23, EET-G24, EET-G25, EET-G26 and EET-G31) bubbles appear to have almost circular shapes (F. 2). By examining the bubble forms on the studied samples, which are generally close to circular and large, it can be said that the glasses were produced by the free-blowing technique.

The element and mineralogical contents of the 10-piece study collection glass samples dating back to the Roman Period were analyzed by a Polarized Energy Dispersive X-Ray Fluorescence Spectrometer (PED-XRF). Furthermore, two samples (in 
EET-G13 and EET-G24) were analyzed by Micro-XRF. These samples (EET-G13 and EET-G24) were chosen from among those that best express the two distinct types of deterioration (iridescence and black discoloration). The degradation layer was analyzed directly by Micro-XRF analysis. The results of the analyzed samples are shown in T. 2-3.

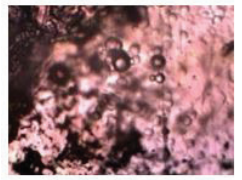

EET-G1

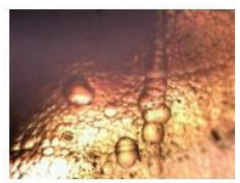

EET-G6

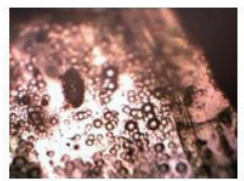

EET-G21

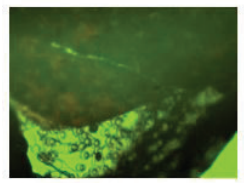

EET-G30

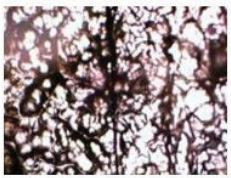

EET-G2

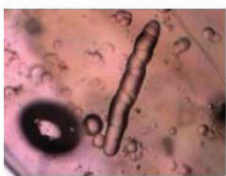

EET-G10

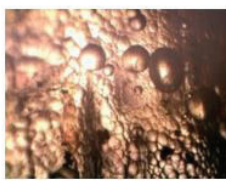

EET-G23

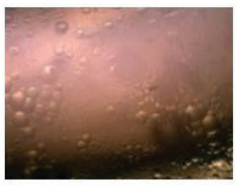

EET-G31

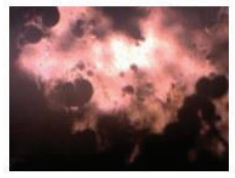

EET-G3

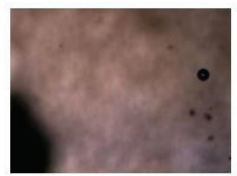

EET-G13

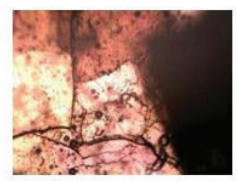

EET-G24

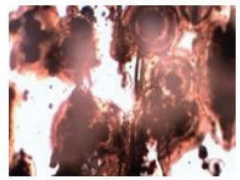

EET-G4

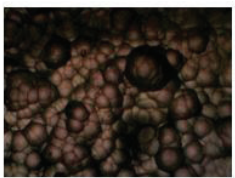

EET-G15

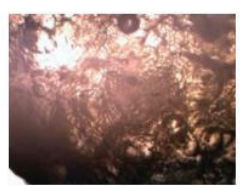

EET-G25

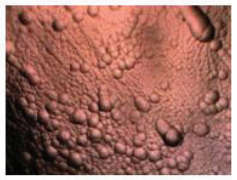

EET-G5

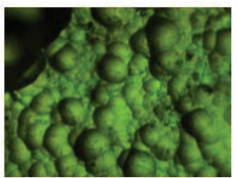

EET-G16

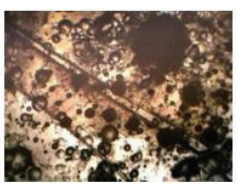

EET-G26

F. 2: Enez Su Terazisi and Kral Kizı regions of the Enez excavation, optical microscope images of deterioration products of glass samples and bubble shapes

(D. Çolak-Büyüksoy, 2019)

PED-XRF analysis revealed that all samples have a soda-lime-silica composition (T. 2). A typical soda-lime-silica glass contains $73 \% \mathrm{SiO}_{2}, 12 \% \mathrm{Na}_{2} \mathrm{O}, 10 \% \mathrm{CaO}, 4 \%$ $\mathrm{MgO}$ and $1 \% \mathrm{Al}_{2} \mathrm{O}_{3} \cdot{ }^{10} \mathrm{Na}_{2} \mathrm{O}$ and $\mathrm{K}_{2} \mathrm{O}$ are alkaline fluxes and $\mathrm{CaO}$ and $\mathrm{MgO}$ are alkaline earth stabilizers. By chemical analysis of archaeological glass objects, a triangular phase diagram was used to support the glass type determined by PED-XRF depending on its main components. The $\mathrm{Na}_{2} \mathrm{O}, \mathrm{K}_{2} \mathrm{O}, \mathrm{MgO}$ and $\mathrm{CaO}$ components of glass artifacts are grouped together, and when shown in the triangular phase diagram, the region categorized as 1 represents the "soda-lime glasses (Iron Age, Antiquity, Early Medieval and Medieval)," the region categorized as 2 represents the "plant ash soda-lime glasses (Middle-Late Bronze Age (Egypt, Mycenaean, Mesopotamia))," the region

10 Aydın et al., "Olba Kazısı Camları Arkeometrik Çalışmaları,” 211. 
categorized as 3 represents the "soda and potash mixed alkali glasses (Late Bronze Age)," and the region categorized as 4 represents the "forest plants ash potash-lime glasses (Medieval)" (F. 3). ${ }^{11}$ The PED-XRF results revealed that Enez glasses are typical soda-lime-silica glass, despite the lower-than-expected silica and sodium content (F. 4). The amount of $\mathrm{Na}_{2} \mathrm{O}$ from the alkali oxides added to the glass contents to reduce the melting point varied between $4.43 \%$ and $17.78 \%$. The $\mathrm{K}_{2} \mathrm{O}$ content ranged from $0.430 \%$ to $1.26 \%$ (T. 2). It is thought that natron was used instead of plant ash as flux since the potassium $(\mathrm{K})$ and magnesium $(\mathrm{Mg})$ contents, which are determinants of the flux used, were lower than $1.5 \%{ }^{12}$ (F. 5).

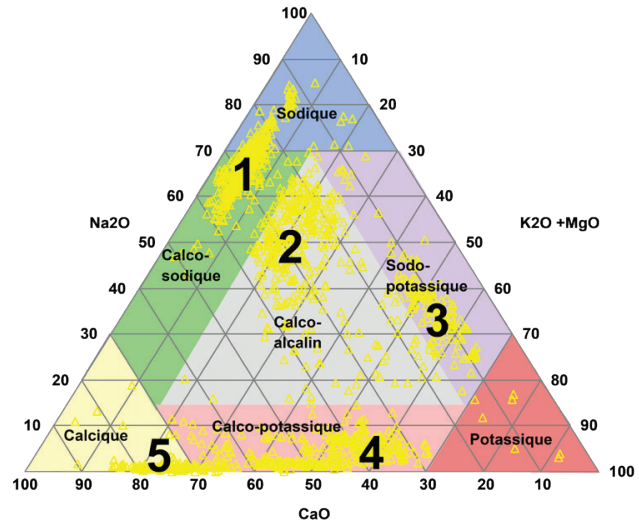

F. 3: Triangle plotting diagram (according to production technique) (Hasdemir, 2016)

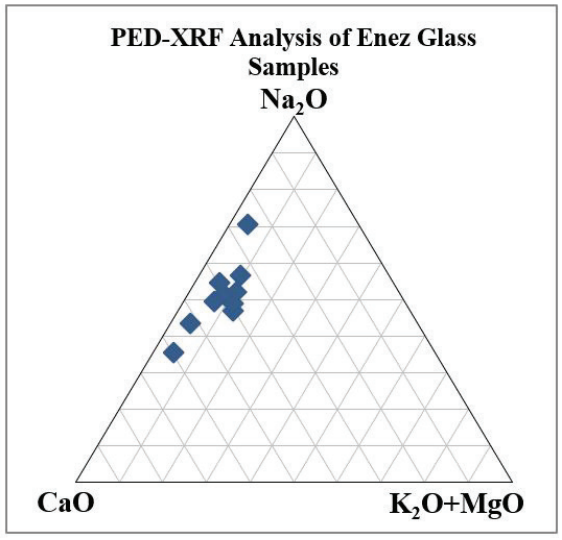

F. 4: Triangle plotting diagram for the studied samples (A. A. Akyol, 2019)

11 İlhan Hasdemir, “Arkeolojik Camların Kimyasına Göre Üretim Yerinin Tespitinde En Son Yöntem; Nadir Element Analizi Yöntemi” (A paper presented at the 'III. Tarihi Eserleri Koruma: Cam Eserler Çalıştayı', Muğla Sualtı Arkeoloji Enstitüsü, 12-14 October 2016).

12 Rebecca B. Scott, and Patrick Degryse, "The Archaeology and Archaeometry of Natron Glass Making," Glass Making in the Greco-Roman World: Results of the ARCHGLASS Project (2014), 21; Robert H. Brill, "Scientific Investigations of the Jalame Glass and Related Finds," Excavations at Jalame: Site of a Glass Factory in late Roman Palestine (1988), 259; Ian C. Freestone et al. "The Origin of Byzantine Glass from Maroni Petrera, Cyprus," Archaeometry 44/2 (2002), 257; Julian Henderson, Ancient Glass: An Interdisciplinary Exploration (New York: Cambridge University Press, 2013), 321. 


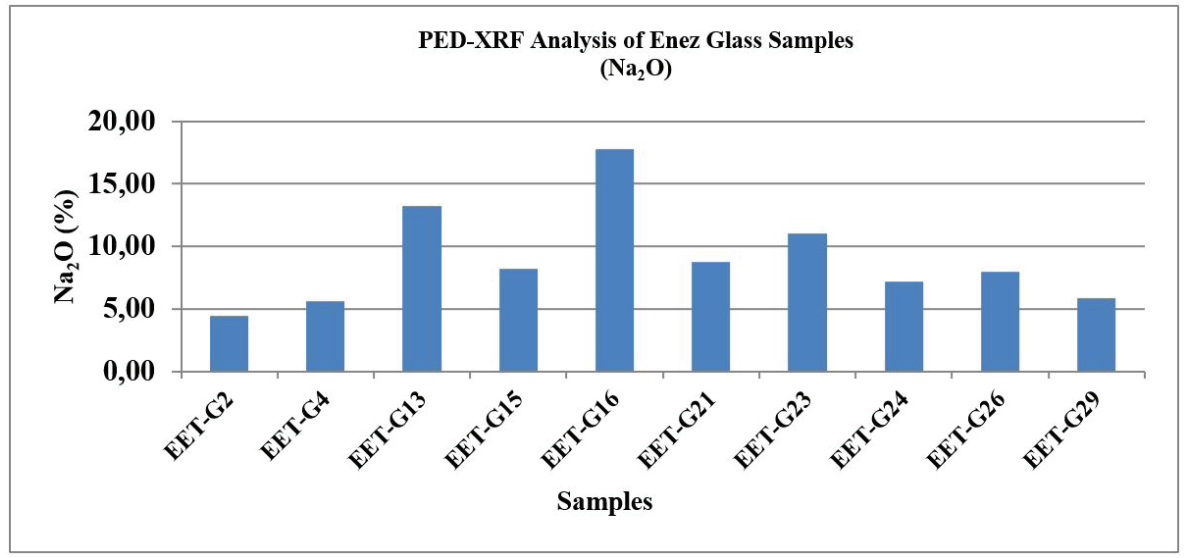

F. 5: PED-XRF analysis of Enez glass samples variation according to $\mathrm{Na}_{2} \mathrm{O}$ content (A. A. Akyol, D. Çolak-Büyüksoy, 2019)

Table 2: The results of PED-XRF analysis of Enez glass samples (Su Terazisi Region) (D. Çolak-Büyüksoy, A. A. Akyol, 2019)

\begin{tabular}{|c|c|c|c|c|c|c|c|}
\hline \multirow[b]{2}{*}{$\begin{array}{l}\text { Element/ } \\
\text { Oxide }\end{array}$} & \multirow[b]{2}{*}{ Unit } & \multicolumn{6}{|c|}{ SU TERAZISI REGION } \\
\hline & & EET-G2 & EET-G4 & EET-G13 & EET-G15 & EET-G16 & Average \\
\hline $\mathrm{Na}_{2} \mathrm{O}$ & \multirow{15}{*}{$\%$} & 4.43 & 5.64 & 13.21 & 8.17 & 17.78 & 9.85 \\
\hline $\mathrm{MgO}$ & & 0.283 & 0.219 & 0.508 & 0.351 & 0.547 & 0.382 \\
\hline $\mathrm{Al}_{2} \mathrm{O}_{3}$ & & 0.678 & 0.689 & 1.54 & 1.13 & 0.503 & 0.908 \\
\hline $\mathrm{SiO}_{2}$ & & 66.46 & 65.00 & 65.61 & 63.26 & 65.86 & 65.24 \\
\hline $\mathrm{P}_{2} \mathrm{O}_{5}$ & & 0.001 & 0.005 & 0.056 & 0.051 & 0.031 & 0.029 \\
\hline $\mathrm{SO}_{3}$ & & 0.193 & 0.167 & 0.495 & 0.246 & 0.349 & 0.290 \\
\hline $\mathrm{Cl}$ & & 0.384 & 0.565 & 0.652 & 0.379 & 0.719 & 0.540 \\
\hline $\mathrm{K}_{2} \mathrm{O}$ & & 0.430 & 0.497 & 0.803 & 0.820 & 0.464 & 0.603 \\
\hline $\mathrm{CaO}$ & & 3.53 & 9.43 & 9.52 & 7.28 & 6.35 & 7.22 \\
\hline $\mathrm{TiO}_{2}$ & & 0.062 & 0.059 & 0.074 & 0.029 & 0.113 & 0.067 \\
\hline $\mathrm{V}_{2} \mathrm{O}_{5}$ & & 0.004 & 0.008 & 0.007 & 0.003 & 0.008 & 0.006 \\
\hline $\mathrm{Cr}_{2} \mathrm{O}_{3}$ & & 0.001 & 0.001 & 0.001 & 0.001 & 0.001 & 0.001 \\
\hline $\mathrm{MnO}$ & & 0.181 & 1.03 & 0.626 & 0.909 & 1.14 & 0.778 \\
\hline $\mathrm{Fe}_{2} \mathrm{O}_{3}$ & & 0.379 & 0.350 & 0.386 & 0.504 & 0.589 & 0.441 \\
\hline LOI* & & 22.33 & 16.83 & 6.73 & 16.63 & 5.92 & 13.69 \\
\hline Co & \multirow{6}{*}{ ppm } & 22 & 20.2 & 29.4 & 14 & 18.5 & 20.82 \\
\hline $\mathrm{Ni}$ & & 5.9 & 10.8 & 7.6 & 7.9 & 11.9 & 8.82 \\
\hline $\mathrm{Cu}$ & & 12.1 & 9 & 76.7 & 33.4 & 21 & 30.44 \\
\hline $\mathrm{Zn}$ & & 11 & 10.3 & 12 & 8.7 & 12 & 10.8 \\
\hline $\mathrm{Ga}$ & & 0.8 & 3.1 & 2.8 & 4.2 & 2.9 & 2.76 \\
\hline $\mathrm{Ge}$ & & 0.6 & 0.3 & 0.3 & 0.3 & 1 & 0.5 \\
\hline
\end{tabular}


T. 2: Continue

\begin{tabular}{|c|c|c|c|c|c|c|c|}
\hline & & \multicolumn{6}{|c|}{ SU TERAZISI REGION } \\
\hline $\begin{array}{l}\text { Element/ } \\
\text { Oxide }\end{array}$ & Unit & EET-G2 & EET-G4 & EET-G13 & EET-G15 & EET-G16 & Average \\
\hline As & \multirow{28}{*}{ ppm } & 10.9 & 1.7 & 2.5 & 1.1 & 2 & 3.64 \\
\hline $\mathrm{Se}$ & & 0.2 & 0.2 & 0.2 & 0.2 & 0.2 & 0.2 \\
\hline $\mathrm{Br}$ & & 5.1 & 6.7 & 12.8 & 5.8 & 5.5 & 7.18 \\
\hline $\mathrm{Rb}$ & & 5.3 & 6.4 & 11.3 & 9.7 & 5.4 & 7.62 \\
\hline $\mathrm{Sr}$ & & 265.7 & 418.3 & 449 & 447.4 & 527.4 & 421.56 \\
\hline $\mathrm{Y}$ & & 1.8 & 5.2 & 5.9 & 4.9 & 6.2 & 4.8 \\
\hline $\mathrm{Zr}$ & & 24.9 & 38.5 & 33.7 & 37.1 & 58.9 & 38.62 \\
\hline $\mathrm{Nb}$ & & 2.1 & 2 & 2.4 & 2.2 & 2.5 & 2.24 \\
\hline Mo & & 2.1 & 2.1 & 2.4 & 3.6 & 2.5 & 2.54 \\
\hline $\mathrm{Cd}$ & & 0.7 & 0.6 & 0.8 & 0.7 & 0.7 & 0.7 \\
\hline In & & 1.1 & 0.6 & 0.9 & 0.6 & 0.7 & 0.78 \\
\hline $\mathrm{Sn}$ & & 9.3 & 0.7 & 9.7 & 2.5 & 1.8 & 4.8 \\
\hline $\mathrm{Sb}$ & & 1054 & 15.2 & 107.2 & 0.7 & 0.7 & 235.56 \\
\hline $\mathrm{Te}$ & & 1 & 1 & 1.2 & 1 & 1.2 & 1.08 \\
\hline I & & 1.6 & 1.7 & 2.2 & 2 & 2.1 & 1.92 \\
\hline Cs & & 2.7 & 3 & 3.9 & 3.3 & 3.6 & 3.3 \\
\hline $\mathrm{Ba}$ & & 64.9 & 252.9 & 268.7 & 1175 & 323.3 & 416.96 \\
\hline $\mathrm{La}$ & & 5.2 & 6.2 & 8.2 & 6.4 & 14.4 & 8.08 \\
\hline $\mathrm{Ce}$ & & 7.3 & 8.5 & 24.8 & 8.8 & 11 & 12.08 \\
\hline $\mathrm{Hf}$ & & 4.6 & 2.2 & 4.8 & 2.4 & 1.5 & 3.1 \\
\hline Ta & & 1.9 & 2 & 4.2 & 2.8 & 2.6 & 2.7 \\
\hline W & & 1.7 & 1.6 & 1.8 & 0.9 & 1.7 & 1.54 \\
\hline $\mathrm{Hg}$ & & 0.5 & 0.5 & 0.6 & 0.5 & 0.6 & 0.54 \\
\hline $\mathrm{Tl}$ & & 0.9 & 0.4 & 0.6 & 0.5 & 0.5 & 0.58 \\
\hline $\mathrm{Pb}$ & & 298 & 5.2 & 88.3 & 45 & 8.5 & 89.0 \\
\hline $\mathrm{Bi}$ & & 0.7 & 0.4 & 0.6 & 0.5 & 0.5 & 0.54 \\
\hline $\mathrm{Th}$ & & 1.3 & 0.6 & 1.7 & 0.8 & 0.9 & 1.06 \\
\hline $\mathrm{U}$ & & 4.5 & 5.2 & 6.1 & 5.6 & 5.4 & 5.36 \\
\hline
\end{tabular}

*LOI (Loss on ignition) 
T. 2: The results of PED-XRF analysis of Enez glass samples (Kral Kiz1 Region)

\begin{tabular}{|c|c|c|c|c|c|c|c|c|}
\hline \multirow[b]{2}{*}{$\begin{array}{l}\text { Element/ } \\
\text { Oxide }\end{array}$} & \multirow[b]{2}{*}{ Unit } & \multicolumn{6}{|c|}{ KRAL KIZI REGION } & \multirow[b]{2}{*}{$\begin{array}{l}\text { General } \\
\text { Average }\end{array}$} \\
\hline & & EET-G21 & EET-G23 & EET-G24 & EET-G26 & EET-G29 & Average & \\
\hline $\mathrm{Na}_{2} \mathrm{O}$ & \multirow{15}{*}{$\%$} & 8.76 & 11.01 & 7.17 & 7.98 & 5.85 & 8.15 & 9.00 \\
\hline $\mathrm{MgO}$ & & 0.771 & 0.805 & 0.679 & 0.378 & 0.530 & 0.633 & 0.507 \\
\hline $\mathrm{Al}_{2} \mathrm{O}_{3}$ & & 1.37 & 2.13 & 2.62 & 0.934 & 2.70 & 1.95 & 1.43 \\
\hline $\mathrm{SiO}_{2}$ & & 59.03 & 59.55 & 62.06 & 64.16 & 64.79 & 61.92 & 63.58 \\
\hline $\mathrm{P}_{2} \mathrm{O}_{5}$ & & 0.082 & 0.208 & 0.040 & 0.019 & 0.055 & 0.081 & 0.055 \\
\hline $\mathrm{SO}_{3}$ & & 0.336 & 0.414 & 0.378 & 0.243 & 0.275 & 0.329 & 0.310 \\
\hline $\mathrm{Cl}$ & & 0.484 & 0.530 & 0.474 & 0.525 & 0.275 & 0.458 & 0.499 \\
\hline $\mathrm{K}_{2} \mathrm{O}$ & & 1.00 & 1.07 & 1.26 & 0.504 & 0.882 & 0.946 & 0.774 \\
\hline $\mathrm{CaO}$ & & 6.23 & 6.67 & 6.16 & 9.58 & 4.80 & 6.69 & 6.95 \\
\hline $\mathrm{TiO}_{2}$ & & 0.181 & 0.199 & 0.204 & 0.214 & 0.202 & 0.200 & 0.134 \\
\hline $\mathrm{V}_{2} \mathrm{O}_{5}$ & & 0.011 & 0.014 & 0.013 & 0.011 & 0.015 & 0.013 & 0.009 \\
\hline $\mathrm{Cr}_{2} \mathrm{O}_{3}$ & & 0.002 & 0.001 & 0.002 & 0.004 & 0.001 & 0.002 & 0.001 \\
\hline $\mathrm{MnO}$ & & 1.56 & 1.64 & 1.20 & 0.953 & 1.69 & 1.41 & 1.09 \\
\hline $\mathrm{Fe}_{2} \mathrm{O}_{3}$ & & 1.40 & 1.36 & 1.44 & 1.31 & 1.09 & 1.32 & 0.881 \\
\hline LOI* & & 18.94 & 14.38 & 16.83 & 13.92 & 16.63 & 16.14 & 14.91 \\
\hline $\mathrm{Co}$ & \multirow{22}{*}{$\mathrm{ppm}$} & 36.9 & 24.6 & 85.6 & 25.6 & 13.9 & 37.32 & 29.1 \\
\hline $\mathrm{Ni}$ & & 31.8 & 24.5 & 42.2 & 14.7 & 34.8 & 29.6 & 19.2 \\
\hline $\mathrm{Cu}$ & & 68.5 & 94.5 & 438.3 & 53.8 & 46.2 & 140.26 & 85.4 \\
\hline $\mathrm{Zn}$ & & 39 & 21.3 & 17.2 & 15.7 & 21.7 & 22.98 & 16.9 \\
\hline $\mathrm{Ga}$ & & 4.4 & 2.7 & 2.1 & 2.6 & 3.1 & 2.98 & 2.9 \\
\hline $\mathrm{Ge}$ & & 0.4 & 0.4 & 0.6 & 0.3 & 0.3 & 0.4 & 0.5 \\
\hline As & & 6.5 & 22.9 & 9.9 & 4.4 & 13.8 & 11.5 & 7.6 \\
\hline $\mathrm{Se}$ & & 0.3 & 0.3 & 0.6 & 0.2 & 0.2 & 0.32 & 0.3 \\
\hline $\mathrm{Br}$ & & 10.9 & 10.2 & 15.7 & 7.2 & 9 & 10.6 & 8.9 \\
\hline $\mathrm{Rb}$ & & 9.8 & 10.1 & 14.9 & 6.9 & 8.8 & 10.1 & 8.9 \\
\hline $\mathrm{Sr}$ & & 801.7 & 655.2 & 726.9 & 375.6 & 521.1 & 616.1 & 518.8 \\
\hline $\mathrm{Y}$ & & 7.6 & 6.4 & 7.8 & 6.5 & 6.3 & 6.92 & 5.9 \\
\hline $\mathrm{Zr}$ & & 115.1 & 91.2 & 106.5 & 120 & 106 & 107.76 & 73.2 \\
\hline $\mathrm{Nb}$ & & 3.1 & 2.6 & 3.1 & 2.5 & 4.4 & 3.14 & 2.7 \\
\hline Mo & & 9.1 & 2.9 & 8.9 & 2.6 & 6.6 & 6.02 & 4.3 \\
\hline $\mathrm{Cd}$ & & 0.9 & 0.8 & 1.4 & 0.6 & 0.7 & 0.88 & 0.8 \\
\hline In & & 1 & 0.8 & 1.3 & 0.6 & 0.7 & 0.88 & 0.8 \\
\hline $\mathrm{Sn}$ & & 14.2 & 16.6 & 71.6 & 23.9 & 50.9 & 35.44 & 20.1 \\
\hline $\mathrm{Sb}$ & & 83.4 & 83.3 & 53.3 & 13.6 & 22.4 & 51.2 & 143.4 \\
\hline $\mathrm{Te}$ & & 1.5 & 1.2 & 1.8 & 1 & 1 & 1.3 & 1.2 \\
\hline I & & 2.8 & 2.2 & 3.5 & 1.8 & 2 & 2.46 & 2.2 \\
\hline $\mathrm{Cs}$ & & 4.9 & 3.7 & 5.6 & 3 & 3 & 4.04 & 3.7 \\
\hline
\end{tabular}


T. 2: Continue

\begin{tabular}{|c|c|c|c|c|c|c|c|c|}
\hline & & & & KRAL KIZ & REGION & & & \\
\hline $\begin{array}{l}\text { Element/ } \\
\text { Oxide }\end{array}$ & Unit & EET-G21 & EET-G23 & EET-G24 & EET-G26 & EET-G29 & Average & $\begin{array}{l}\text { General } \\
\text { Average }\end{array}$ \\
\hline $\mathrm{Ba}$ & & 334.4 & 391 & 301.9 & 245 & 253.9 & 305.24 & 361.1 \\
\hline $\mathrm{La}$ & & 11 & 9.2 & 12 & 11.8 & 6.3 & 10.06 & 9.1 \\
\hline $\mathrm{Ce}$ & & 28.4 & 25.5 & 17 & 8.6 & 8.7 & 17.64 & 14.9 \\
\hline $\mathrm{Hf}$ & & 3.7 & 7.1 & 28.5 & 5.4 & 3.8 & 9.7 & 6.4 \\
\hline $\mathrm{Ta}$ & & 4.3 & 4.8 & 11 & 3.4 & 3.4 & 5.38 & 4.0 \\
\hline W & & 2.3 & 1.9 & 2.9 & 1.6 & 1.8 & 2.1 & 1.8 \\
\hline $\mathrm{Hg}$ & ppm & 0.6 & 0.6 & 1.1 & 0.5 & 0.6 & 0.68 & 0.6 \\
\hline $\mathrm{Tl}$ & & 0.8 & 0.9 & 2.6 & 0.5 & 0.7 & 1.1 & 0.8 \\
\hline $\mathrm{Pb}$ & & 90.1 & 248.6 & 1663 & 95.8 & 107.6 & 441.02 & 265.0 \\
\hline $\mathrm{Bi}$ & & 0.7 & 0.9 & 2.2 & 0.6 & 0.7 & 1.02 & 0.8 \\
\hline $\mathrm{Th}$ & & 1.5 & 2.4 & 12.5 & 1.4 & 1.8 & 3.92 & 2.5 \\
\hline $\bar{U}$ & & 6.8 & 6.6 & 7.3 & 5.5 & 5.8 & 6.4 & 5.9 \\
\hline
\end{tabular}

The visible color of the samples was greenish, bluish and brown. However, in the results of 10 samples analyzed by PED-XRF, it was understood that the samples have greenish colors. As a result of PED-XRF analysis, the colour of the glass samples can be attributed to the elements of iron $(\mathrm{Fe})$, cobalt $(\mathrm{Co})$ and copper $(\mathrm{Cu})$. The glass sample EET-G24 was determined as light blue as a result of color measurement. In the result of PED-XRF, the highest cobalt (Co) content was found in EET-G24 (85.6 ppm). Furthermore, in this example, the copper $(\mathrm{Cu})$ ratio was $438.3 \mathrm{ppm}$ and the lead $(\mathrm{Pb})$ was $1663 \mathrm{ppm}$. By comparison with the data of $\mathrm{L} * \mathrm{a} * \mathrm{~b} *$ values, (a) value was -2.56 and $(\mathrm{b})$ value was -2.13 (T. 1). It is seen that lead $(\mathrm{Pb})$ was also added along with copper $(\mathrm{Cu})$ to create a dominant green color. ${ }^{13}$ For example, the light bluish visible color may have been formed as a result of light refraction caused by the deterioration layer on the surface. However, it can be determined that the color of the sample is green due to the dominant copper $(\mathrm{Co})$ and lead $(\mathrm{Pb})$ values. It is also known that lead $(\mathrm{Pb})$ causes degradation at different levels depending on the chemical content of the glass. Glasses with high lead $(\mathrm{Pb})$ content show the fastest deterioration rate, unlike glasses with more stable silica content. ${ }^{14}$ In color measurement, the colors of EET-G23, EET-G26 and EET-G29 samples could not be determined due to the dete-

13 Irina F. Kadikova et al., "Study of Deteriorating Turquoise Lead-Potassium Glass Beads at Different Stages of Corrosion Using Micro-FTIR Spectroscopy," Submitted to Materials Today: Proceedings (2017), 4-5; Akyol and Kadığlu, "Tekfur Sarayı Cam Buluntuları Arkeometrik Çalışmaları,” 34; Akyol et al., "İstanbul Koca Ragıb Paşa Kütüphanesi Camları Arkeometrik Analizleri," 9; Bernard Gratuze et al., "Changes in the Signature of Cobalt Colorants in Late Antique and Early Islamic Glass Production," Minerals 8/6 (2018), 1.

14 Teresa Palomar et al., "Hydrolytic Resistance of $\mathrm{K}_{2} \mathrm{O}-\mathrm{PbO}-\mathrm{SiO}_{2}$ Glasses in Aqueous and High-Humidity Environments," Journal of the American Ceramic Society 103/9 (2020),10. 
rioration layer on the surface and the color was detected as brown due to the brown layer. However, as a result of the PED-XRF analysis, it can be said that the samples have a greenish color due to their consistent and low cobalt $(\mathrm{Co})$ content and relatively high copper $(\mathrm{Cu})$ and lead $(\mathrm{Pb})$ contents.

In the EET-G1 sample, where the color was determined to be bluish-green in the color measurement; Egyptian blue, a pigment with calcium copper silicate $(\mathrm{CaCu}-$ $\mathrm{Si}_{4} \mathrm{O}_{10}$ cuprorivaite), which supports this result, was also detected by Raman analysis between 381-1068 $\mathrm{cm}^{-1}$ peak points (F. 6).

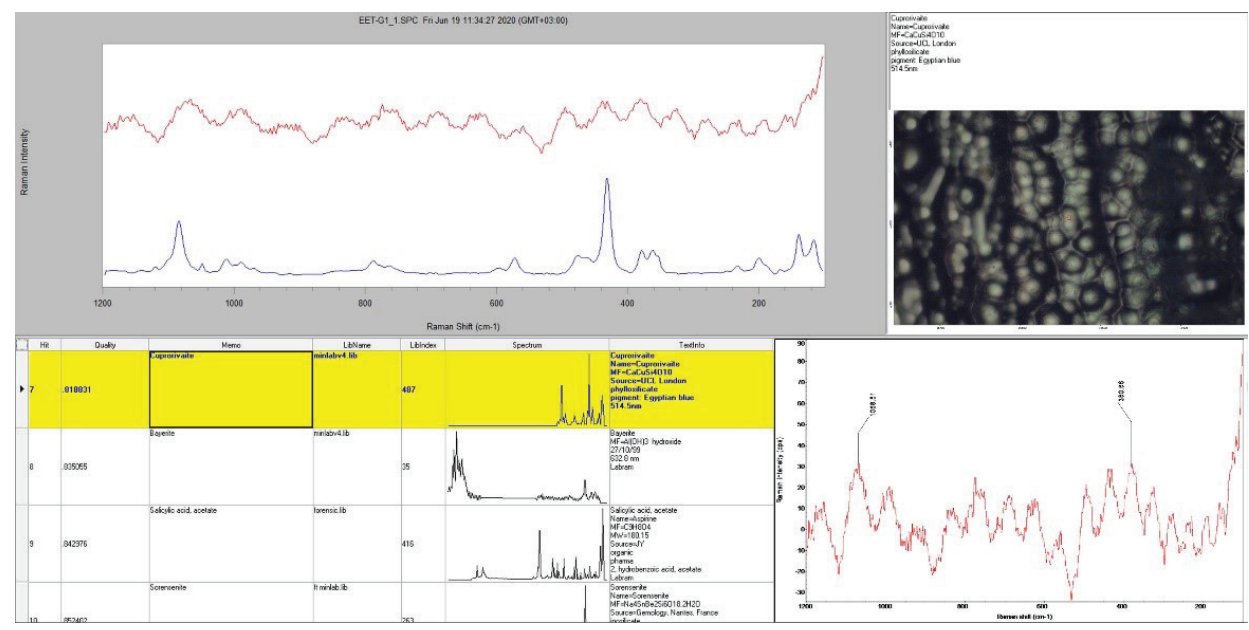

F. 6: Pigment cuprorivaite $\left(\mathrm{CaCuSi}_{4} \mathrm{O}_{10}\right)$ determined by Raman analysis for EET-G1 sample (D. Çolak-Büyüksoy, A. A. Akyol, 2020)

Manganese (Mn), which gives a purple color to the glass and was also used as a decolorizer, was between $0.181 \%$ and $1.69 \%$. Manganese $(\mathrm{Mn})$ being more than $0.4 \%$, means that it was added to the glass deliberately. ${ }^{15}$ Even though manganese (Mn) was found at an average rate of $1.09 \%$, there was no colorless glass among the samples studied. This can be explained by the fact that Fe, which has an average rate of $0.881 \%$ (between $0.35-1.44 \%$ ) in the glass content, gives blue or green tones to the glass. Only one sample (EET-G2) had a higher antimony (Sb) (1054 ppm) content than others. $\mathrm{Sb}$, another decolorizer, must have failed to give the expected effect since it acts as a reducer in the furnace environment, as this sample was bluish-green in color. Sb was also known to be added to the glass as a substance to remove the bubble trapped in the glass. As the surface deterioration of the samples affects the visualization of the bubbles in the microscopic examinations, the antimony's fining properties cannot be observed in the EET-G2 sample with especially high antimony content. 
Strontium (Sr) and its isotopes are a powerful method to identify both raw materials and origins of antique glasses. Most of the strontium in the glass possibly comes from lime-bearing components in the glass (a sea shell containing calcium carbonate or limestone, lime-rich plant ash). Strontium (Sr) and zirconium ( $\mathrm{Zr}$ ) amounts can give information about the origin of the sand used in production. The high amount of $\mathrm{Sr}$ ( $>400 \mathrm{ppm}$ ) indicates that the sand used in production was most likely of maritime origin. In terrestrial sands, it is expected that the amount of Sr will be less than 150 ppm and the amount of $\mathrm{Zr}$ will be more than $160 \mathrm{ppm} .{ }^{16}$ In the PED-XRF results, the strontium ( $\mathrm{Sr}$ ) content ranged from $265.7 \mathrm{ppm}$ to $801.7 \mathrm{ppm}$. The strontium (Sr) contents of the two samples (EET-G2 and EET-G26) were below 400 ppm; however, they did not present the terrestrial sand features either. The general $\mathrm{Sr}$ content of the samples was above $400 \mathrm{pm}$, indicating that the sand used in production was most likely maritime in origin (F. 7). In addition, the barium (Ba) content was more than 300 ppm in 5 samples and especially in the EET-G15 sample it had a value as high as 1175 ppm. In the same samples, $\mathrm{Al}_{2} \mathrm{O}_{3}$ content was also more than $1 \%$. These results suggest that sand that was rich in alkali feldspar was used in the production of glasses. ${ }^{17}$

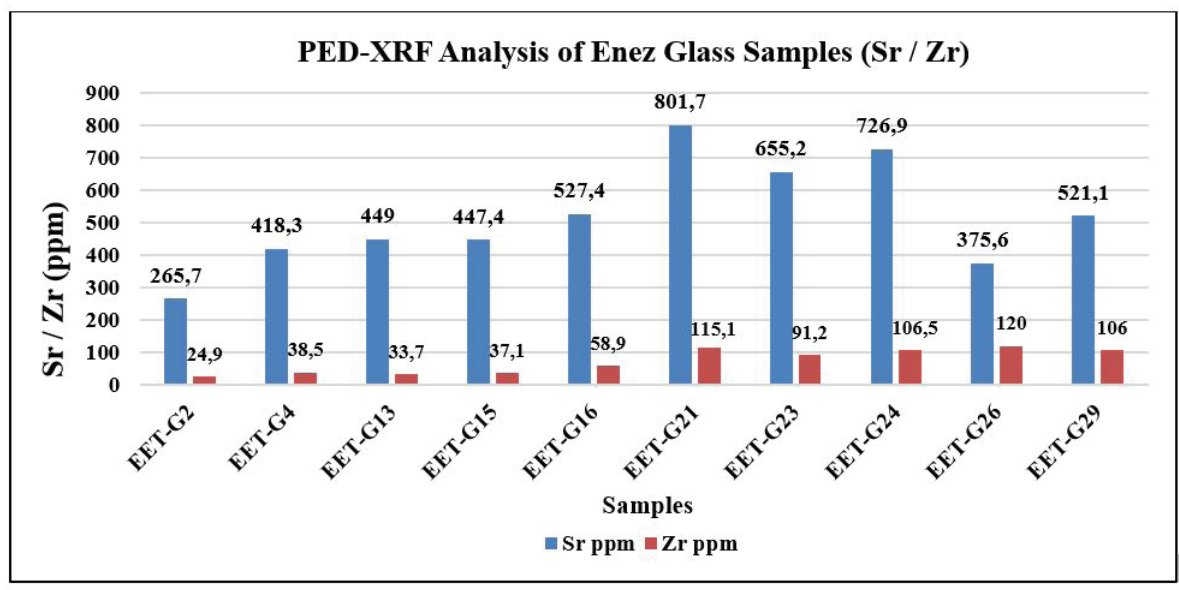

F. 7: PED-XRF analysis of Enez glass samples variation according to Strontium ( $\mathrm{Sr}$ ) and Zirconium (Zr) contents (D. Çolak-Büyüksoy, 2019)

\section{Analyses of Deterioration Layers}

In optical microscope images of glass samples, the deterioration layers on the surface prevented the transparent view, so the bubble images on the glass could not be ob-

16 K. Hans Wedepohl and Albrecht Baumann, "The Use of Marine Molluskan Shells for Roman Glass and Local Raw Glass Production in the Eifel Area (Western Germany)," Naturwissenschaften 87/3 (2000), 129-130; Ian C. Freestone et al., "Strontium Isotopes in the Investigation of Early Glass Production: Byzantine and Early Islamic Glass from the Near East," Archaeometry 45/1 (2003); Ali Akın Akyol et al., "İstanbul Koca Ragıb Paşa Kütüphanesi Camları Arkeometrik Analizleri,” Journal of Turkish Studies 9/10 (2014), 10.

17 Alberta Silvestri et al. "The colourless glass of Iulia Felix," Journal of Archaeological Science 35 (2008), 338-339. 
tained clearly. Circular black appearances in the samples' images, albeit few, give the image of a bubble in the glass. However, deterioration products were also displayed in all images due to the deterioration layers seen on the glass surface. For example, in the deterioration table of EET-G1 (T. 4), the deterioration degree was determined as a 2 (light) and the deterioration degree of EET-G15 as a 4 (very heavy). When the microscopic images of these two samples were compared, the image of the deterioration products was smaller in EET-G1 and much larger in EET-G15. Deterioration degrees that are shown in Table 4 support the microscope images (F. 2).

T. 3: The results of Micro-XRF analysis of Enez glass samples (D. Çolak-Büyüksoy, A. A. Akyol, 2019)

\begin{tabular}{|c|c|c|c|}
\hline Element & Unit & EET-G13 & EET-G24 \\
\hline $\mathrm{Mg}$ & \multirow{30}{*}{$\%$} & 6.62 & 8.90 \\
\hline $\mathrm{Al}$ & & 3.84 & 3.38 \\
\hline $\mathrm{P}$ & & 0.090 & 0.090 \\
\hline $\mathrm{S}$ & & 0.080 & 0.080 \\
\hline $\mathrm{Ti}$ & & 0.087 & 0.162 \\
\hline V & & 0.010 & 0.016 \\
\hline $\mathrm{Cr}$ & & 0.008 & 0.005 \\
\hline $\mathrm{Mn}$ & & 0.142 & 1.25 \\
\hline $\mathrm{Fe}$ & & 0.450 & 0.749 \\
\hline $\mathrm{Co}$ & & 0.003 & 0.004 \\
\hline $\mathrm{Ni}$ & & 0.015 & 0.015 \\
\hline $\mathrm{Cu}$ & & 0.010 & 0.009 \\
\hline $\mathrm{Zn}$ & & 0.003 & 0.002 \\
\hline $\mathrm{Ga}$ & & 0.010 & 0.001 \\
\hline $\mathrm{Zr}$ & & 0.050 & 0.050 \\
\hline $\mathrm{Nb}$ & & 0.094 & 0.098 \\
\hline Mo & & 0.083 & 0.076 \\
\hline $\mathrm{Rh}$ & & 0.002 & 0.002 \\
\hline $\mathrm{Pd}$ & & 0.004 & 0.004 \\
\hline $\mathrm{Ag}$ & & 0.004 & 0.005 \\
\hline $\mathrm{Cd}$ & & 0.005 & 0.005 \\
\hline In & & 0.006 & 0.006 \\
\hline $\mathrm{Sn}$ & & 0.007 & 0.007 \\
\hline $\mathrm{Sb}$ & & 0.011 & 0.012 \\
\hline W & & 0.005 & 0.003 \\
\hline $\mathrm{Ir}$ & & 0.001 & 0.001 \\
\hline $\mathrm{Pt}$ & & 0.020 & 0.020 \\
\hline $\mathrm{Au}$ & & 0.020 & 0.020 \\
\hline $\mathrm{Pb}$ & & 0.014 & 0.012 \\
\hline Total & & 26.29 & 21.95 \\
\hline
\end{tabular}


The types of deterioration determined in the samples were iridescence, dulling, black discoloration and pitting. The morphology of the alteration layer of archaeological glass fragments depends on environment. ${ }^{18}$ Water and accumulated moisture in the environment are the most important factors that start and resume the deterioration of glass. Those reactions are highly dependent on the glass composition, its production temperature in kiln and firing duration and $\mathrm{pH}$ of the medium around glass. In acidic media, sodium $\left(\mathrm{Na}_{2} \mathrm{O}\right)$ and potassium $\left(\mathrm{K}_{2} \mathrm{O}\right)$ ions, which are in the structure of the glass and added to the glass as a flux, form sodium or potassium hydroxides by exchanging hydrogen ions when water and moisture are present in the surrounding environment. This process creates a hydrated surface layer rich in silica, sometimes referred to as the gel layer. ${ }^{19}$ This layer has rich $\mathrm{Si}$ content and poor $\mathrm{Ca}, \mathrm{N}$ and $\mathrm{K}$ content. In this way, the gel layer creates a superficial layer on the glass surface that delays or prevents further chemical attack. ${ }^{20}$ At high $\mathrm{pH}$ values, hydroxide ions attack the bridging $\mathrm{Si}-\mathrm{O}-\mathrm{Si}$ bonds and cause the dissolving of the glass matrix. ${ }^{21}$

Surfaces of glasses exposed to weathering in aqueous environments undergo after long periods of time considerable alteration due to ion exchange, hydration and hydrolysis resulting in opaque crusts or iridescent layers. ${ }^{22}$ Iridescence occurs due to leaching resulting in a few micrometers of fine porous gel layers on the surface (EET-G6; F. 1 and F. 2, T. 4). Successive multiple layers, almost parallel to each other, interfere with the direct transmission of light through the glass, causing an iridescent appearance on the surface. ${ }^{23}$ Dulling is one of the types of deterioration in glass that loses its original clarity and transparency and becomes translucent, quite different from dulling caused by scratches or stains (EET-G2; F. 1 and F. 2, T. 4) ${ }^{24}$ When the deterioration is in the form of pitting, the size of the pits formed on the entirety or only part of the glass surface can be very small (0.1-0.2 $\mathrm{mm})$, as well as large with a diameter of $5 \mathrm{~mm}$, with or without white deposit (EET-G25;

18 İlhan Hasdemir et al. "Micromechanical Properties of Banded Alterations of Archaeological Glass Fragments," Journal of Non-Crystalline Solids 376 (2013), 126.

19 Hannelore Römich, "Glass and Ceramics," Conservation Science: Heritage Materials (Cambridge: Royal Society of Chemistry, 2006), 164; Michael Mäder et al., "Non-destructive Evaluation of Glass Corrosion States," Nuclear Instruments and Methods in Physics Research Section B: Beam Interactions with Materials and Atoms 136 (1998), 863; Stephen P. Koob, Conservation and Care of Glass Objects (New York: Archetype Yayınları, 2006), 13.

20 Ceren Baykan, Toprak Altı Cam Buluntuların Koruma ve Onarımı (İstanbul: Homer Kitabevi, 2014), 52.

21 Hannelore Römich, "Glass and Ceramics," 164.

22 İlhan Hasdemir et al. "Micromechanical Properties of Banded Alterations of Archaeological Glass Fragments," 126.

23 Anna M. Gueli et al. "Weathering and Deterioration of Archeological Glasses from Late Roman Sicily," International Journal of Applied Glass Scence 11 (2020), 219; Sandra Davison, Conservation and Restoration of Glass (London: Butterworths, 2006), 183; Koob, Conservation and Care of Glass Objects, 14; Alberta Silvestri et al. "Archaeological Glass Alteration Products in Marine and Land-Based Environments: Morphological, Chemical and Microtextural Characterization," Journal of Non-Crystalline Solids 351 (2005), 1346.

24 Davison, Conservation and Restoration of Glass, 183. 
F. 1 and F. 2, T. 1). ${ }^{25}$ Black discoloration on the glass surface can be caused by the oxidation of iron and manganese ions (EET-G26; F. 1 and F. 2, T. 1). ${ }^{26}$

The high amount of $\mathrm{SiO}_{2}$, the key material found as a glass former in the composition of the glass, indicates that the mechanical resistance and durability of glass are high and the glass has a high melting point. The fact that the amount of $\mathrm{CaO}$ added as a stabilizer to the glass together with the glass former $\left(\mathrm{SiO}_{2}\right)$ is less than the current production rates, decreases the durability of the glass and decreases its resistance to deterioration. ${ }^{27}$ In the result of PED-XRF analysis, the $\mathrm{SiO}_{2}$ content varied between $59.03 \%$ and $66.46 \% . \mathrm{SiO}_{2}$ content was lower than expected (F. 8). The reduced $\mathrm{SiO}_{2}$ content as a result of the deterioration of the glass over time supports the deterioration seen on the glass surface. ${ }^{28} \mathrm{SiO}_{2}$, which was low in the general structure of glass, was higher in the deterioration layer. As the deterioration progresses, Si enrichment occurs in the gel layer. The results of SEM-EDS analysis of the samples appear to have a higher $\mathrm{SiO}_{2}$ content compared to PED-XRF (T. 2 and T. 5).

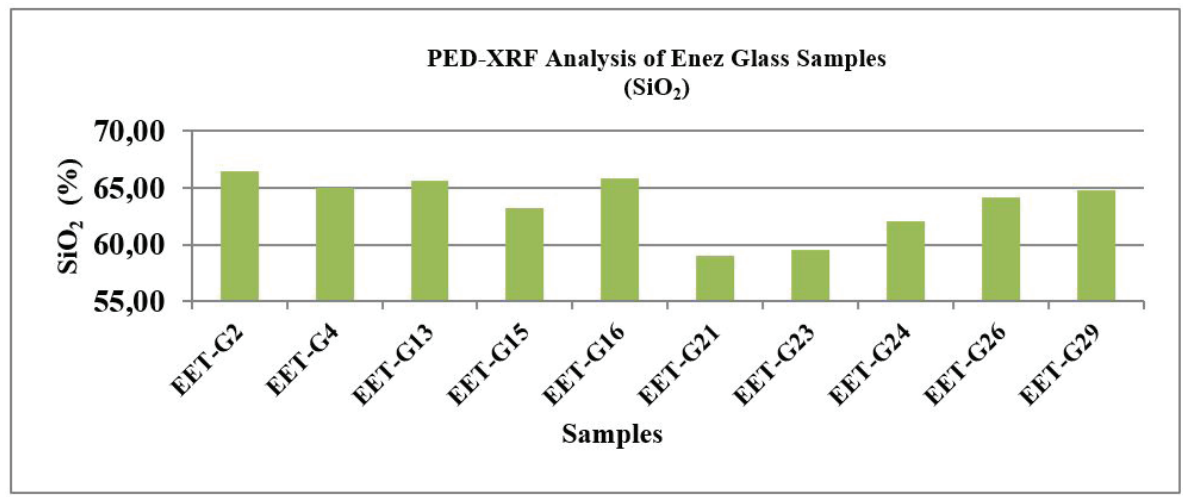

F. 8: PED-XRF analysis of Enez glass samples variation according to their $\mathrm{SiO}_{2}$ content (A. A. Akyol, D. Çolak-Büyüksoy, 2019)

While the $\mathrm{Na}_{2} \mathrm{O}$ content in the general structure of the glass can be observed between $12-18 \%$, it is expected that the $\mathrm{Na}_{2} \mathrm{O}$ content in the gel layer formed on the glass surface

25 Emine N. Caner-Saltık, “Arkeometrik Çalışmalar Işı̆̆ında Belirlenen Cam Bozulmaları,” II. ODTÜ Arkeometri Çalıştayl. Türkiye Arkeolojisi'nde Cam: Arkeolojik ve Arkeometrik Çalışmalar Kitabı (Ankara: ODTÜ Yayınları, 2012), 58.

26 David Watkinson et al. "Staining of Archaeological Glass from Manganese-Rich Environments," Archaeometry 47/1 (2005).

27 Akyol et al., "İstanbul Koca Ragıb Paşa Kütüphanesi Camları Arkeometrik Analizleri," 5.

28 Ali Akın Akyol et al., "İstanbul Yeni Cami Hünkar Kasrı Camları Üzerine Arkeometrik Çalışmalar," II. ODTÜ Arkeometri Çalıştayl-Türkiye Arkeolojisi’nde Cam: Arkeolojik ve Arkeometrik Çalışmalar Bildiri Kitabı (Ankara: ODTÜ Yayıncılık, 2012), 161; Akyol and Kadığlu, "Tekfur Sarayı Cam Buluntuları Arkeometrik Çalışmaları," 33. 
will decrease due to the glass objects being in humid environments. ${ }^{29}$ EET-G13 and EET-G16 samples had the highest $\mathrm{Na}_{2} \mathrm{O}$ value (13.21\% and $17.78 \%$, respectively) and their $\mathrm{CaO}$ content was respectively $9.52 \%$ and $6.35 \%$. These two examples did not contain a dense deterioration layer, except for partial deterioration zones. The high sodium ratio in these two samples may also be related to the surface deposit due to the marine effect. While chlorine was generally below $0.50 \%$, the fact that it was above $0.65 \%$ in EET-G13 and EET-G16 samples also support the marine effect.

The $\mathrm{CaO}$ content added as a stabilizer to the glass ranged from $3.53 \%$ to $9.58 \%$ and $\mathrm{MgO}$ content ranges from $0.219 \%$ to $0.805 \%$ (T. 2). The low amount of $\mathrm{CaO}$ is effective in reducing the resistance of the glass against deterioration. $\mathrm{CaO}$ content was found as expected in the 8 samples except for EET-G2 and EET-G29 samples. In these two samples (EET-G2 and EET-G29) the $\mathrm{CaO}$ content was quite low $(3.53 \%$ and $4.80 \%$, respectively). In the EET-G2 sample, there was intense iridescence formation and in the EET-G29 sample, intense black discoloration formation was observed (F. 1). The fact that these two samples also have low sodium content is due to the deterioration of the glass. Among the samples, EET-G4, EET-G13 and EET-G26 samples appear to have higher $\mathrm{CaO}$ content than the other samples (F. 9). Examining T. 4, it is seen that the deterioration of the EET-G4 sample was at an early level (very light). The difference of the EET-G4 sample from the other two samples was that it has high $\mathrm{CaO}$ content $(9.43 \%)$ as well as low $\mathrm{Na}_{2} \mathrm{O}$ content $(5.64 \%)$. The balance between $\mathrm{CaO}$ and $\mathrm{Na}_{2} \mathrm{O}$ supports the early level of deterioration in the sample.

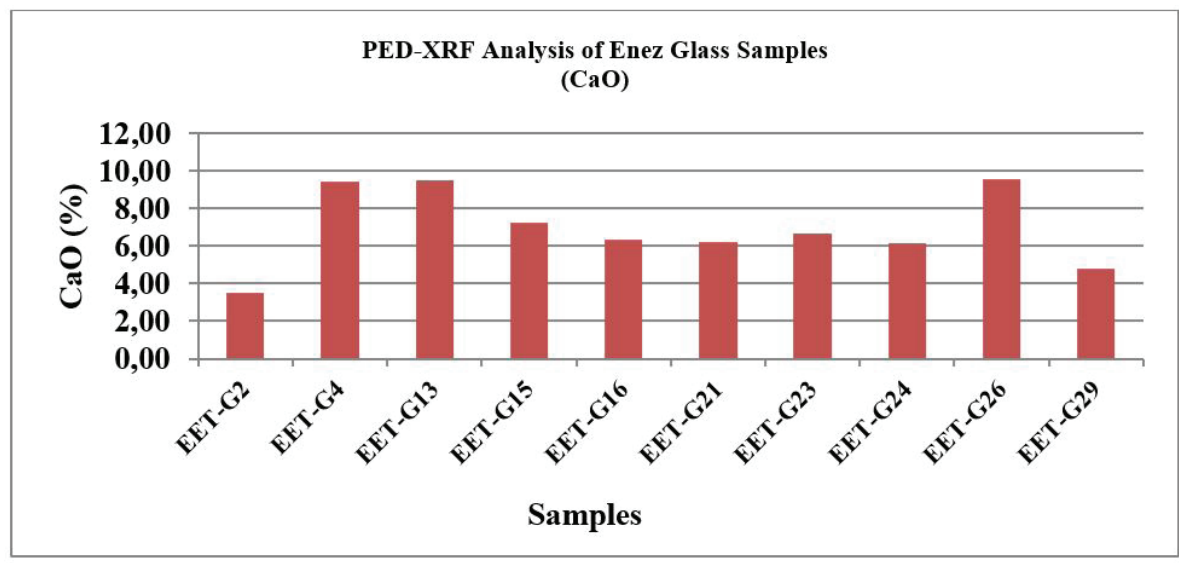

F. 9: PED-XRF analysis of Enez glass samples variation according to their $\mathrm{CaO}$ content (A. A. Akyol, D. Çolak-Büyüksoy, 2019)

29 Dirk Johannes Huisman et al., "Degradation Processes in Roman Glass: Cases from the Bocholtz Burial," Journal of Archaeological Science 35/2 (2008), 404-405. 
Micro-XRF analysis was performed directly on the layer of iridescence and black discoloration formation among the samples selected for Raman analysis (T. 3). Since these two samples (EET-G13 and EET-G24) represent two different degradations, they also wanted to be supported by Micro-XRF analysis. The analysis performed on the samples taken from the iridescence layer of EET-G13 and from the black discoloration layer of EET-G24, aimed to draw attention to the Mn and Fe elements. The results of PED-XRF analysis showed that the manganese (Mn) content in the EET-G13 sample was $0.626 \%$ and the iron $(\mathrm{Fe})$ content was $0.386 \%$; meanwhile the result of the Micro-XRF analysis showed that the manganese content was $0.142 \%$ and the iron content was $0.450 \%$. The manganese level is not expected to be high since the iridescence layer of this sample was analyzed. However, a relatively high increase was seen in the iron content, which is to be expected. Also, the high aluminum content found in the iridescence layer taken from the EET-G13 sample is another result that can be related to deterioration. The manganese content, which is expected to be high in the black discoloration layer, shows a high value in the EET-G24 sample. As the result of the PED-XRF analysis shows, the manganese (Mn) content was $1.20 \%$ and the iron (Fe) content was $1.44 \%$; the manganese content was $1.25 \%$ and the iron content was $0.749 \%$ as a result of the Micro-XRF analysis.

Table 4: Visual identification of deterioration in Enez glasses (D. Çolak-Büyüksoy, I. Özsait-Kocabaş, 2018)

\begin{tabular}{|l|c|c|c|c|}
\hline Sample & Iridescence & Dulling & Pitting & Black discoloration \\
\hline EET-G1 & 2 & 2 & 0 & 0 \\
\hline EET-G2 & 3 & 3 & 1 & 0 \\
\hline EET-G3 & 2 & 3 & 3 & 1 \\
\hline EET-G4 & 1 & 0 & 1 & 0 \\
\hline EET-G5 & 1 & 0 & 1 & 0 \\
\hline EET-G6 & 4 & 0 & 4 & 4 \\
\hline EET-G10 & 1 & 0 & 1 & 3 \\
\hline EET-G12 & 2 & 0 & 1 & 3 \\
\hline EET-G13 & 3 & 1 & 2 & 4 \\
\hline EET-G15 & 1 & 2 & 2 & 3 \\
\hline EET-G16 & 1 & 0 & 1 & 4 \\
\hline EET-G21 & 3 & 0 & 2 & 3 \\
\hline EET-G23 & 2 & 0 & 0 & 3 \\
\hline EET-G24 & 1 & 2 & 0 & 4 \\
\hline EET-G25 & 3 & 3 & 4 & 4 \\
\hline EET-G26 & 3 & 0 & 0 & 4 \\
\hline EET-G29 & 2 & 2 & 2 & 4 \\
\hline EET-G30 & 3 & 0 & 0 & 1 \\
\hline EET-G31 & 2 & 0 & & \\
\hline
\end{tabular}

0 : None; 1: Very light; 2: Light 3: Heavy; 4: Very heavy 
Deterioration processes affect the correlation between chemical compounds in glass such as glass former $\left(\mathrm{SiO}_{2}\right)$, fluxes $\left(\mathrm{K}_{2} \mathrm{O}\right.$ and $\left.\mathrm{Na}_{2} \mathrm{O}\right)$ and stabilizers $(\mathrm{CaO}$ and $\mathrm{MgO})$ differently. ${ }^{30}$ All types of deterioration processes show strong sodium depletion, often combined with an increase in the amount of silica and aluminum. In addition to these, $\mathrm{Fe}_{2} \mathrm{O}_{3}$ is expected to increase. This is expected to occur concerning the dissolution of the silica network due to hydration after leaching. Unlike iridescence or dulling type deterioration caused by the leaching of alkali and alkaline soil ions, black discoloration formation may be caused by the migration of $\mathrm{Mn}, \mathrm{Fe}$ and other metallic ions entering the glass from the surrounding soil by water affecting the glass ${ }^{31}$ or may be caused by oxidation of iron and manganese ions present in the glass. ${ }^{32}$

Usually, the content of $\mathrm{SiO}_{2}$ and $\mathrm{Al}_{2} \mathrm{O}_{3}$ increase in deteriorated glasses because they are formers and difficult to leach from the glass but it is expected to be depleted in iron $(\mathrm{Fe})$ rich layers and $\mathrm{Mn}$-rich layers close to the surface. Besides, if the $\mathrm{pH}$ exceeds 9 , the silica matrix also begins to dissolve. While higher $\mathrm{Na}_{2} \mathrm{O}$ values are observed in the general structure of glass, it is expected that $\mathrm{Na}_{2} \mathrm{O}$ will decrease significantly in all kinds of deteriorated glass. ${ }^{33}$ Also, the calcium $(\mathrm{CaO})$ content too, is expected to decrease as a result of leaching; however, it may increase systematically in layers due to calcite formation. Other minor elements such as potassium, magnesium and chlorine are rich in the deteriorated area, possibly due to the formation of salty crusts favored by the moist environment. Chlorine exists in glass in ionic form and is soluble in glass matrix only in very small amounts (typically less than $2 \%$ in soda-lime-silica glass). The presence of chlorine ions on deteriorated surfaces can be explained by salts formed in situ, especially for increased values concerning mass. Generally, its existence is related to marine environments. ${ }^{34}$

The SEM-EDS results of the samples generally show that the $\mathrm{SiO}_{2}$ and $\mathrm{Al}_{2} \mathrm{O}_{3}$ contents were higher than the PED-XRF results (T. 2 and T. 5). $\mathrm{SiO}_{2}$ content was between $63.70 \%$ and $79.57 \% . \mathrm{Al}_{2} \mathrm{O}_{3}$ content was between $2.48 \%$ and $6.58 \%$. This situation is associated with the increase of $\mathrm{SiO}_{2}$ and $\mathrm{Al}_{2} \mathrm{O}_{3}$ contents in deteriorated glasses. EET-G2 and EET-G24 samples provide data for comparison since both anal-

30 Ramadan Abd-Alla, "Devitrification Behaviour of Corroded Glass: Four Cases Study," Mediterranean Archaeology and Archaeometry 7/1 (2007), 41.

31 Silvestri et al., "Archaeological Glass Alteration Products in Marine and Land-Based Environments: Morphological, Chemical and Microtextural Characterization," 1346; G. A. Cox and B. A. Ford, "The long-term corrosion of glass by ground-water," Journal of Materials Science 28 (1993), 5637; Watkinson et al. "Staining of Archaeological Glass from Manganese-Rich Environments," 79.

32 Gueli et al., "Weathering and Deterioration of Archeological Glasses from Late Roman Sicily," 219.

33 Maria-Teresa Doménech-Carbo et al., "A study on Corrosion Processes of Archaeological Glass from the Valencian Region (Spain) and Its Consolidation Treatment," Microchimica Acta 154/1-2 (2006), 132; Aurélie Verney-Carron et al., "Understanding the Mechanisms of Si-K-Ca Glass Alteration Using Silicon Isotopes," Geochimica et Cosmochimica Acta 203 (2017), 417; Römich, "Glass and Ceramics," Conservation Science: Heritage Materials, 164.

34 Gueli et al., "Weathering and Deterioration of Archeological Glasses from Late Roman Sicily," 223-224. 
yses (PED-XRF and SEM-EDS) were performed. In the PED-XRF analysis results, the $\mathrm{SiO}_{2}$ and $\mathrm{Al}_{2} \mathrm{O}_{3}$ contents of EET-G2 were $66.46 \%$ and $0.678 \%$, respectively, while the $\mathrm{SiO}_{2}$ and $\mathrm{Al}_{2} \mathrm{O}_{3}$ contents were $75.16 \%$ and $4.74 \%$, respectively, in the SEM-EDS analysis results. In the PED-XRF analysis results, the $\mathrm{SiO}_{2}$ and $\mathrm{Al}_{2} \mathrm{O}_{3}$ contents of EET-G24 were $62.06 \%$ and $2.62 \%$, respectively, while the $\mathrm{SiO}_{2}$ and $\mathrm{Al}_{2} \mathrm{O}_{3}$ contents were $72.62 \%$ and $5.03 \%$, respectively, in the SEM-EDS analysis results (T. 6). The reason for the difference between these two analyses was that in the PED-XRF analysis, the sample was examined after being powdered to obtain information about the general structure of the glass and in SEM-EDS analysis, the surface of the deteriorated layer was examined.

Table 5: The results of SEM-EDS analysis of Enez glass samples (D. Çolak-Büyüksoy, A. A. Akyol, 2019)

\begin{tabular}{|l|l|c|c|c|c|c|c|c|c|c|c|c|}
\hline \multirow{2}{*}{ No } & \multirow{2}{*}{ Sample } & \multicolumn{10}{|c|}{ Element or Oxide (\%) } \\
\cline { 3 - 14 } & & $\mathbf{N a}_{2} \mathbf{O}$ & $\mathbf{M g O}$ & $\mathbf{A l}_{2} \mathbf{O}_{3}$ & $\mathbf{S i O}_{2}$ & $\mathbf{S O}_{3}$ & $\mathbf{C l}$ & $\mathbf{K}_{2} \mathbf{O}$ & $\mathbf{C a O}$ & $\mathbf{T i O}_{2}$ & $\mathbf{M n O}$ & $\mathbf{F e O}$ \\
\hline 1 & EET-G1 & 9.31 & 0.97 & 4.19 & 75.09 & 0.25 & 0.81 & 0.68 & 7.94 & 0.14 & 0.27 & 0.37 \\
\hline 2 & EET-G2 & 6.52 & 0.78 & 4.74 & 75.16 & 1.66 & 1.14 & 0.77 & 8.48 & 0.04 & 0.28 & 0.44 \\
\hline 3 & EET-G3 & 19.88 & 0.76 & 2.48 & 67.72 & 0.5 & 1.31 & 0.39 & 6.17 & 0.03 & 0.3 & 0.45 \\
\hline 4 & EET-G5 & 3.68 & 0.84 & 6.58 & 76.98 & 0.16 & 0.60 & 0.57 & 8.04 & 0.31 & 1.22 & 1.02 \\
\hline 5 & EET-G6 & 9.39 & 1.48 & 4.33 & 71.25 & 0.49 & 0.83 & 0.69 & 8.04 & 0.28 & 1.49 & 1.72 \\
\hline 6 & EET-G10 & 4.36 & 0.7 & 6.35 & 79.57 & 0.12 & 0.57 & 0.44 & 6.97 & - & 0.5 & 0.43 \\
\hline 7 & EET-G12 & 19.8 & 1.57 & 3.30 & 64.23 & 0.32 & 0.97 & 0.37 & 5.68 & 0.4 & 2.14 & 1.22 \\
\hline 8 & EET-G24 & 10.24 & 1.52 & 5.03 & 72.62 & 0.29 & 0.53 & 1.07 & 6.38 & 0.11 & 1.12 & 1.08 \\
\hline 9 & EET-G25 & 19.21 & 1.12 & 3.11 & 63.70 & 0.35 & 0.80 & 0.66 & 8.95 & 0.18 & 1.06 & 0.86 \\
\hline 10 & EET-G30 & 4.89 & 1.11 & 5.58 & 76.53 & 0.15 & 0.42 & 0.87 & 7.84 & 0.3 & 0.84 & 1.48 \\
\hline \multicolumn{1}{l}{ ORTALAMA } & 10.73 & 1.08 & 4.57 & 72.28 & 0.43 & 0.80 & 0.65 & 7.45 & 0.2 & 0.92 & 0.91 \\
\hline
\end{tabular}

Table 6: Comparison of glass components according to PED-XRF and SEM-EDS analyses (D. Çolak-Büyüksoy, 2019)

\begin{tabular}{|c|c|c|c|c|c|}
\hline \multirow{3}{*}{$\begin{array}{l}\text { Oxide } \\
(\%)\end{array}$} & \multicolumn{3}{|c|}{ EET-G2 (Iridescence) } & \multicolumn{2}{|c|}{ EET-G24 (Black discoloration) } \\
\hline & PED-XRF & SEM-EDS & PED-XRF & Micro-XRF & SEM-EDS \\
\hline & $\begin{array}{c}\text { Bulk } \\
\text { Glass }\end{array}$ & $\begin{array}{c}\text { Deterioration } \\
\text { Layer }\end{array}$ & Bulk Glass & Deterioration Layer & Deterioration Layer \\
\hline $\mathrm{SiO}_{2}$ & 66.46 & 75.16 & 62.06 & - & 72.62 \\
\hline $\mathrm{Na}_{2} \mathrm{O}$ & 4.43 & 6.52 & 7.17 & - & 10.24 \\
\hline $\mathrm{CaO}$ & 3.53 & 8.48 & 6.16 & - & 6.38 \\
\hline $\mathrm{K}_{2} \mathrm{O}$ & 0.430 & 0.77 & 1.26 & - & 1.07 \\
\hline $\mathrm{MgO}$ & 0.283 & 0.78 & 0.679 & - & 1.52 \\
\hline $\mathrm{Al}_{2} \mathrm{O}_{3}$ & 0.678 & 4.74 & 2.62 & 3.38 & 5.03 \\
\hline $\mathrm{Fe}_{2} \mathrm{O}_{3}$ & 0.379 & 0.44 & 1.44 & 0.749 & 1.08 \\
\hline $\mathrm{MnO}$ & 0.181 & 0.28 & 1.20 & 1.25 & 1.12 \\
\hline
\end{tabular}


In the SEM-EDS analysis results, the $\mathrm{Na}_{2} \mathrm{O}$ content varied between $3.68 \%$ and $19.88 \%$. The $\mathrm{CaO}$ content varied between $5.68 \%$ and $8.95 \%$. The $\mathrm{Na}_{2} \mathrm{O}$ and $\mathrm{CaO}$ contents of the samples were expected to be low due to the gel layer formed as a result of leaching; however, it had a high $\mathrm{Na}_{2} \mathrm{O}$ content of $19.88 \%$. It is thought that this has been caused by the environment where the glasses were, that is, the marine environment. The $\mathrm{Na}_{2} \mathrm{O}$ contents of the EET-G3, EET-G12 and EET-G25 samples were considerably higher than the other samples. The relative $\mathrm{Cl}$ contents of the same samples $(1.31 \%, 0.97 \%$ and $0.80 \%$ respectively) were also high. Again, it can be said that these contents were higher due to the marine effect. Four samples (EET-G6, EET-G12, EET-G24 and EET-G30) had relatively high $\mathrm{MnO}$ and FeO content. In these samples, the very heavy black discoloration formation supports the results of $\mathrm{MnO}$ and $\mathrm{FeO}$. Manganese and iron ratios were quite prominent in the deterioration layers (for example, in EET-G12 example, Mn 2.14\%, Fe 1.22\%). These were at the minor element (1-2\%) level (T. 5).

In the scanning electron microscope (SEM) images of the samples, deteriorations on the glass surface can be observed (F. 10). Their number and density increased with increasing leaching time, that is, with increasing layer thickness. ${ }^{35}$ Pitting formations that were invisible in the EET-G1 sample and visible at the early level in the EET-G2 sample can be clearly observed from the SEM images. Pitting on the glass can clearly be seen from the SEM images of the EET-G5 and EET-G6 samples. In the EET-G6 sample, pitting was more advanced and areas where surface deterioration layers are flaking can be seen. In the EET-G10 sample, intense flaking caused by the formation of black discoloration was observed. In the EET-G24 sample, flaking can be seen due to the formation of iridescence and black discoloration. SEM images of the EET-G25 and EET-G30 samples give images similar to the optical microscope images.

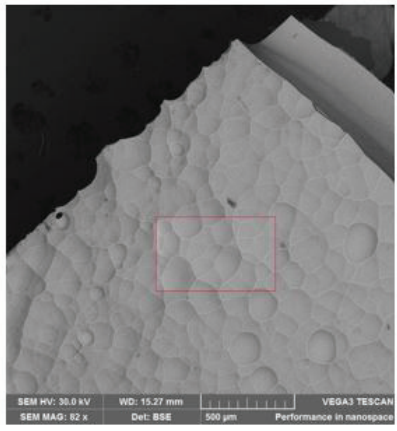

EET-G1

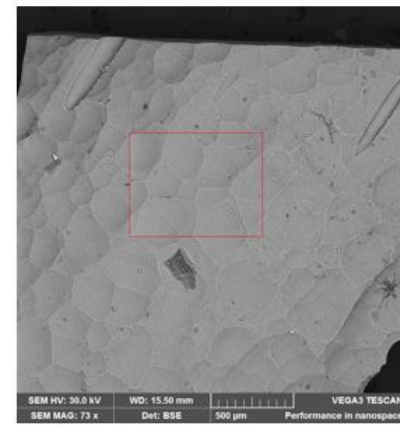

EET-G2

35 Mäder et al., "Non-destructive Evaluation of Glass Corrosion States," 866. 


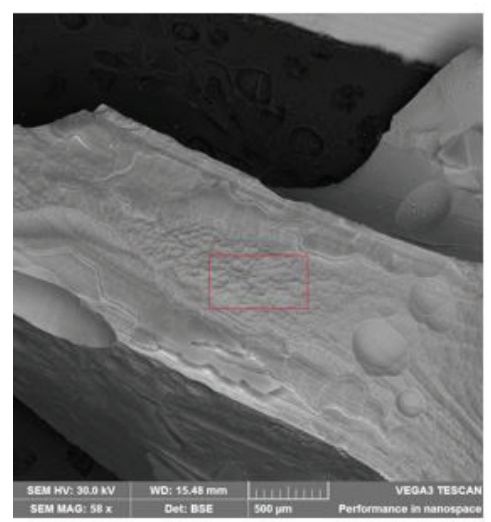

EET-G5

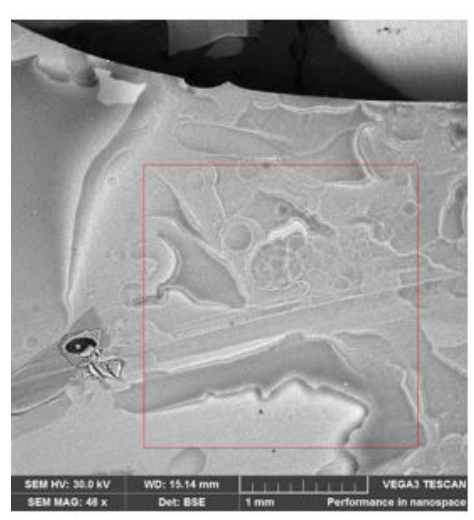

EET-G10

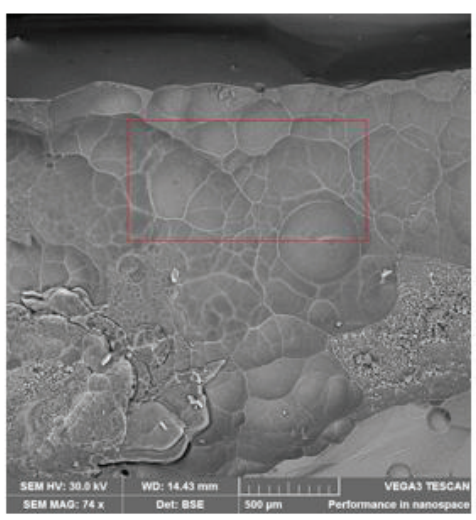

EET-G25

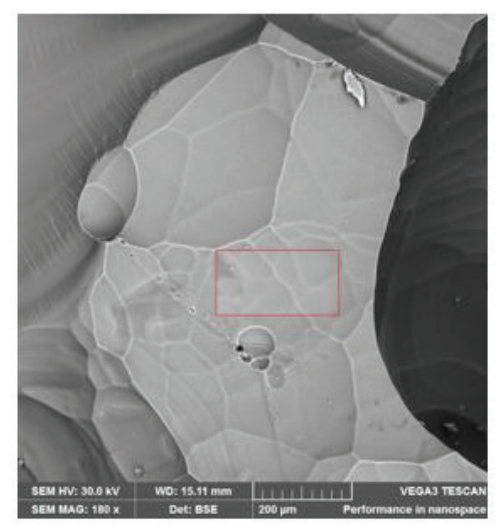

EET-G6

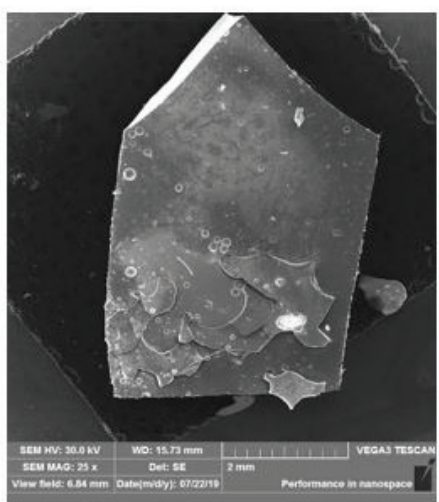

EET-G24

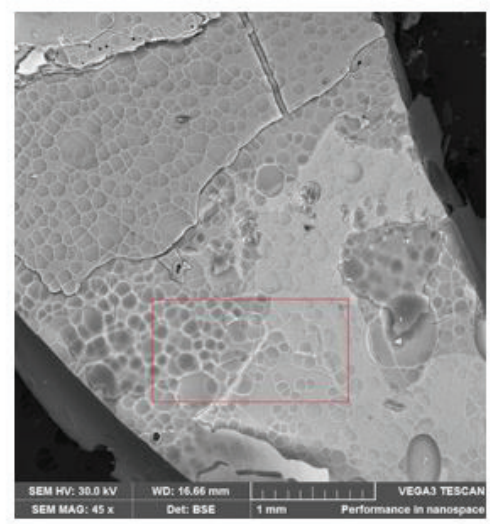

EET-G30

F. 10: SEM analysis images of Enez glass samples (Images were taken for this study by the Turkish Cultural Foundation, Cultural Heritage Preservation and Natural Dyes Laboratory.) 
Manganese (Mn) levels in antique glasses are around 1\%. Black discoloration formation layers show a thin laminated structure with Mn-rich and Fe-rich regions. ${ }^{36}$ Gaps caused by micro-cracks increase the possibility of penetrating the body of the glass and generating deterioration. It is highly probable that the deposits of $\mathrm{Mn}, \mathrm{Fe}, \mathrm{Ca}$ and $\mathrm{P}$ near the surface of the glass are of soil origin. ${ }^{37}$ According to another opinion, black discoloration formation may be caused by oxidation of iron and manganese ions present in the glass. ${ }^{38} \mathrm{Fe}_{2} \mathrm{O}_{3}$ content of less than $0.5 \%$ enters the glass from the sand used in glass production. Similarly, $\mathrm{MnO}$ content lower than $1 \%$ can be found as an impurity in the glass composition. Nevertheless, iron and manganese can also be deliberately present in colorless glasses at concentrations ranging from about $0.5 \%$ to $1 \%$ to decolorize glass. ${ }^{39}$

Confocal Raman analysis was performed on the EET-G1, EET-G13, EET-G24 and EET-G31 samples selected from among the researched glass samples. In the library of the device, the blue peaks in the graphs show the equivalent of the peak of the mineral in the library's reference, while the red peaks show the results of the analyzed samples. While the iron content was expected to be high, especially in the black discoloration, the presence of iron content should also be expected in other types of deterioration layers. In the following Raman results, these results were obtained in both the black discoloration and iridescence layer.

The manganese observed in the black discoloration mentioned above could be detected as a mineral between $287-623 \mathrm{~cm}^{-1}$ peaks by Raman analysis in the samples of EET-G13 and EET-G24, as in the PED-XRF and SEM-EDS analyses (F. 11). These were already among the samples with the highest manganese values in the analysis results. In consideration of this, analysis results that support each other, the presence of manganese was embodied in the presence of the black discoloration formation layer seen with the naked eye in the studied samples.

36 Teresa Palomar, "Characterization of the Alteration Processes of Historical Glasses on the Seabed," Materials Chemistry and Physics 214 (2018), 394.

37 Silvestri et al., "Archaeological Glass Alteration Products in Marine and Land-Based Environments: Morphological, Chemical and Microtextural Characterization," 1345-1346; Watkinson et al. "Staining of Archaeological Glass from Manganese-Rich Environments," 79.

38 Gueli et al., "Weathering and Deterioration of Archeological Glasses from Late Roman Sicily," 219.

39 Doménech-Carbo et al., "A study on Corrosion Processes of Archaeological Glass from the Valencian Region (Spain) and Its Consolidation Treatment," 130; Pilario Costagliola et al., "Mineralogical and Chemical Characterisation of the Medicean Glass Mosaic Tesserae and Mortars of the Grotta del Buontalenti, Giardino di Boboli, Florence, Italy," Journal of Cultural Heritage 1 (2000), 295. 
(a)

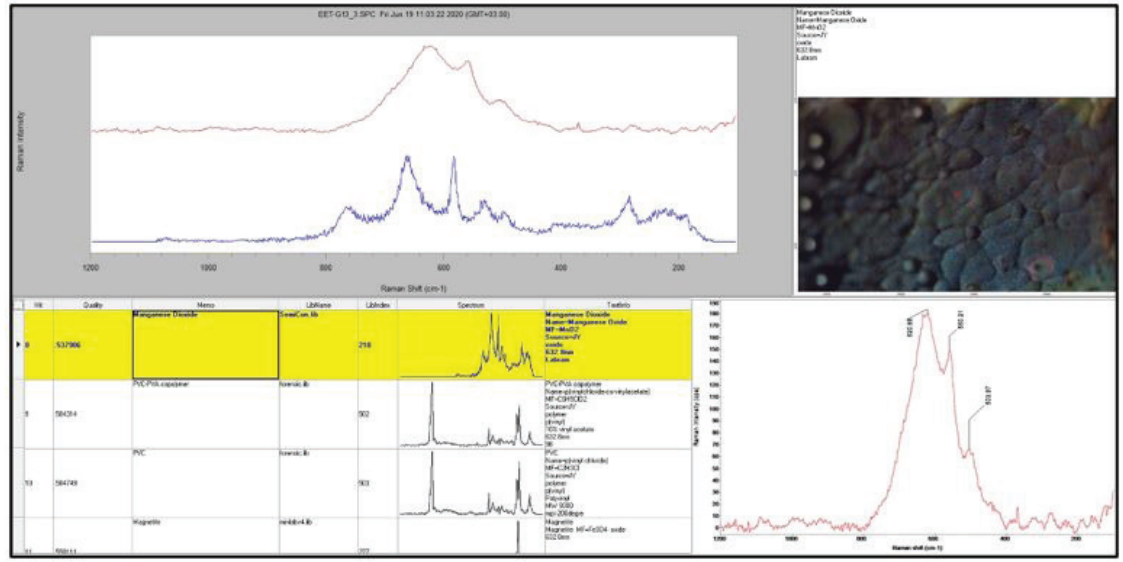

(b)

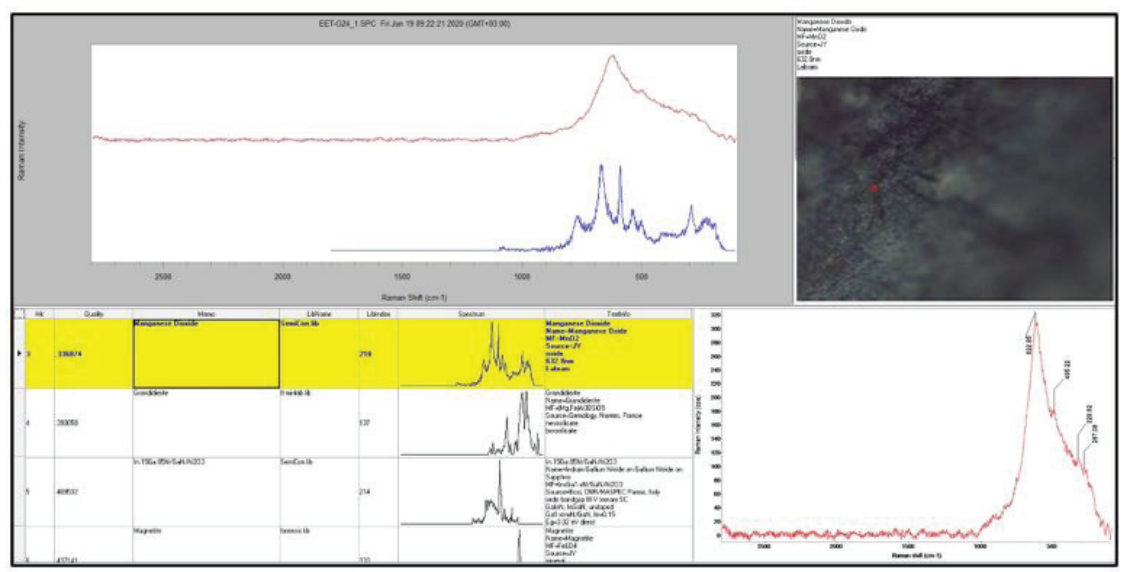

F. 11: Manganese determined by Raman analysis in black discoloration layers of EET-G13 (a) and EET-G24 (b) samples (D. Çolak-Büyüksoy, A. A. Akyol, 2020)

As it is known, iron was often used as a coloring material. But another element that causes black discoloration formation was iron. The peaks of iron are between $287-1094 \mathrm{~cm}^{-1}$ and in the Raman analysis of the black discoloration formations of the samples EET-G13, EET-G24 and EET-G31, magnetite $\left(\mathrm{Fe}_{3} \mathrm{O}_{4}\right)$ and goethite minerals indicating the presence of iron were detected (F. 12). 
(a)

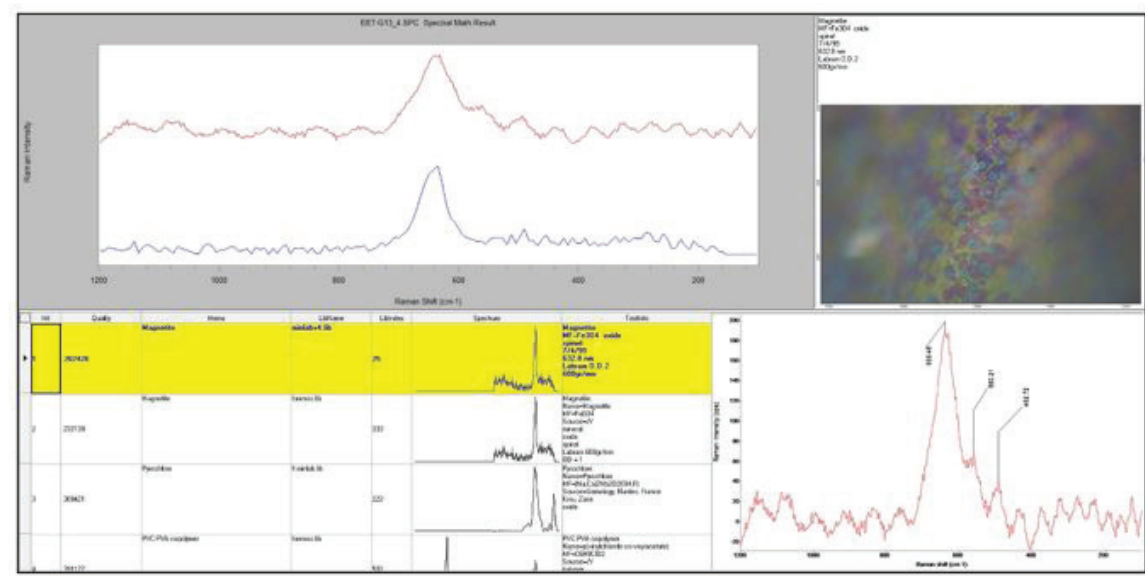

(b)

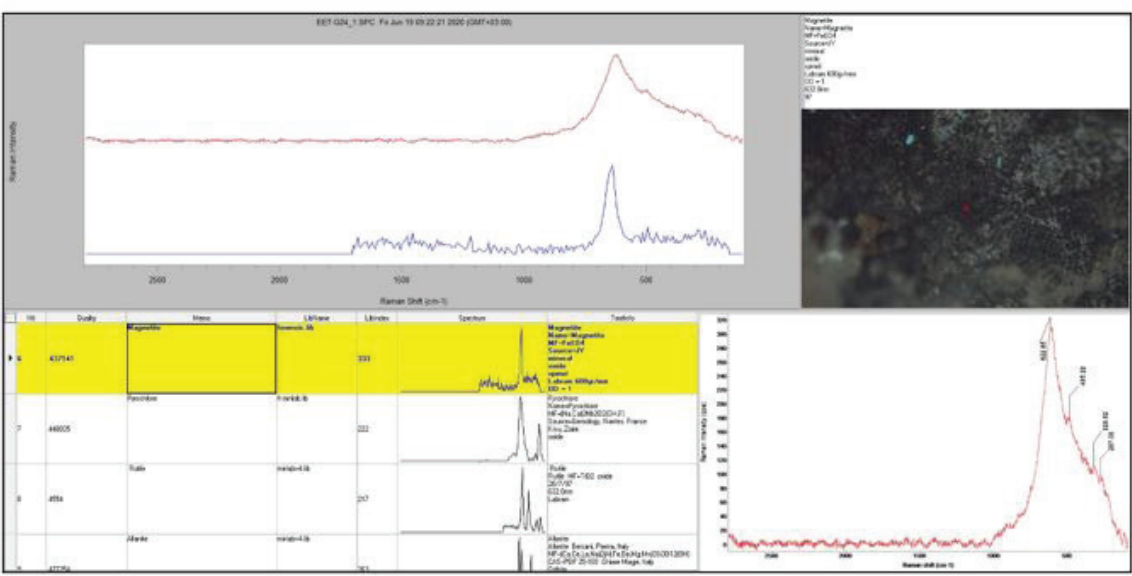

(c)

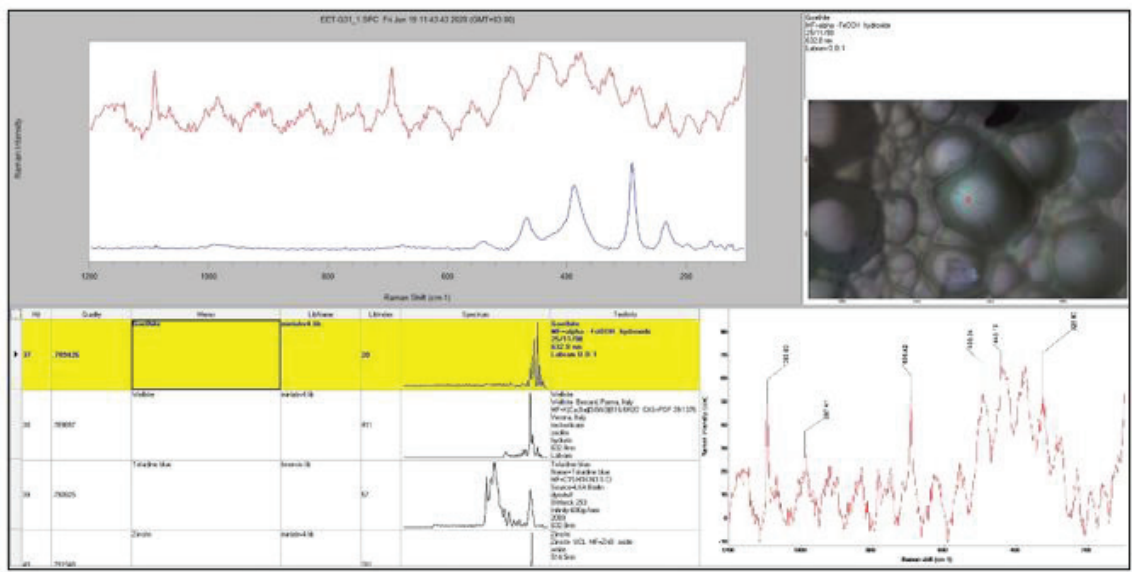

F. 12: Iron determined by Raman analysis in black discoloration layers of EET-G13 (a), EET-G24 (b) and EET-G31 (c) samples (D. Çolak-Büyüksoy, A. A. Akyol, 2020) 
Like the Mn value was in the Micro-XRF, PED-XRF and SEM-EDS analyses results of the EET-G24 sample, the Fe value was also relatively high. These results support the black discoloration formation seen on the glass surface. While unfortunately a comparison could not be made, as the result of the SEM-EDS analysis of the EET-G13 sample was not available; the existence of Fe was found with the Raman analysis results.

\section{Conclusion}

Within the scope of this study, research was carried out to determine the chemical content of glass and the deterioration caused by its chemical content on 19-piece study collection samples dated to the Roman Period. The study collection glasses were examined visually and chemically. Coding, thickness measurement and documentation of the samples with detailed photographs were carried out in a laboratory environment. Visual examination of the deteriorations present on the surface of the glass was made and a table was prepared by determining the types and degrees of deterioration. In the optical microscope examinations of the samples, the deterioration products that can support the deterioration layer seen on the glass surface were determined. Since the deterioration products prevent the transparent appearance of the glass, the bubbles that provide information about the production technique of glass, which can be partially determined, were generally observed in near-circular and large forms and by looking at these figures it can be said that the glasses were produced by the free-blowing technique.

Polarized Energy Dispersive-X-Ray Fluorescence (PED-XRF), Scanning Electron Microscope-Energy Dispersive Spectrometry (SEM-EDS) and Raman (Confocal) Spectroscopy methods were used to determine the element and mineralogical contents of the glass samples. According to the results of the analysis, when the contents of silica-calcium-sodium were evaluated, the glass samples were found to be typical soda-lime-silica glass. When the strontium (Sr) and zirconium $(\mathrm{Zr})$ contents were evaluated (high strontium content, low zirconium content), it was determined that the source of silica that had been used in the production of glass, in general, was of marine (coastal) origin. The low content of potassium and magnesium indicates that natron was used as a flux instead of plant ash. As a result of the color measurement, it was determined that the colors of the samples were greenish-bluish tones. The elements of $\mathrm{Fe}, \mathrm{Co}$ and $\mathrm{Cu}$ were the colorants for the glasses.

When the deterioration layers of the samples dating back to the Roman Period were examined visually and with an optical microscope, the types of deterioration caused by the change in the chemical composition of the glass such as iridescence, dulling, black discoloration and pitting were identified. The types of deterioration seen in 
glasses were evaluated according to their degree of deterioration (T. 4). Iridescence was observed to be very light in 6 , light in 6 , heavy in 6 and very heavy in 1 out of 19 samples. Dulling was observed to be light in 1, light in 4 and heavy in 3 out of 19 samples. Pitting was observed to be very light in 7, light in 4, heavy in 1 and very heavy in 2 out of 19 samples. Black discoloration was observed to be very light in 1, heavy in 5 and very heavy in 9 out of 19 samples.

The high amount of $\mathrm{SiO}_{2}$, which was used as a former in the glass, increases the mechanical resistance of the glass. As a result of the PED-XRF analysis of the samples, the $\mathrm{SiO}_{2}$ content was determined to be $63.58 \%$ on average. The reason for the lower-than-expected $\mathrm{SiO}_{2}$ content is the deteriorations that can be observed on the glass. The high $\mathrm{SiO}_{2}$ content in the deterioration layer supports the deterioration seen in the glasses in the comparison between the two samples (EET-G2 and EET-G24), which have been analyzed both by PED-XRF and SEM-EDS methods (T. 6). It was expected that the amount of flux $\left(\mathrm{Na}_{2} \mathrm{O}\right)$ and stabilizer $(\mathrm{CaO})$ would decrease in the gel layer that is formed on the surface due to the contact of glass objects with moisture and/or water. However, the high amount of $\mathrm{Na}_{2} \mathrm{O}$ and $\mathrm{CaO}$ in the results of the SEMEDS analysis of the samples is thought to be due to the deposits formed as a result of the marine effect, since the ancient city was located very close to the sea.

In the scanning electron microscopy (SEM) images of the 8 samples selected among the samples, deteriorations on the surface of the sample were also detected. Pitting formation on the glass surface, which can also be seen with the naked eye, iridescence and flaking on the surface after the formation of black discoloration can be clearly observed in the SEM images obtained.

The black discoloration formation layers were characterized by its manganese content. Along with the high manganese content, the iron content was expected to be high. As a result of Micro-XRF, PED-XRF and SEM-EDS analyses of the glass samples, while manganese and iron stand out in black discoloration type's degradation products, the presence of manganese and iron detected by Raman analysis supports these results.

As a result of Raman analysis, besides the manganese and iron content that could be associated with the deterioration layers, the pigment content that could support the color of the bluish-green color was revealed.

No samples were obtained of the excavation soil containing the glass artifacts examined in this study. But, in order to evaluate the effects of long-term burial on glass, it is useful to take samples from the soil from which the glass object came out during the excavation. The presence of soluble salts as well as the $\mathrm{pH}$ of the surrounding soil or groundwater can be helpful to explain the current state of glass deterioration and predict future deterioration. 
Peer-review: Externally peer-reviewed.

Conflict of Interest: The authors have no conflict of interest to declare.

Grant Support: This study was funded by the Scientific Research Projects Coordination Unit of Istanbul University. Project number: 34068 .

Acknowledgement: The authors owe a debt of gratitude to the Scientific Research Projects Coordination Unit of Istanbul University, Prof. Dr. Sait Başaran, Prof. Dr. Yusuf Kağan Kadioğlu and Assist. Prof. Dr. Kıymet Deniz (Ankara University, Earth Science Application and Research Center-YEBIM) for the XRF and Raman analyses, Emine Torgan Güzel (Turkish Cultural Foundation, Cultural Heritage Preservation and Natural Dyes Project) for SEM-EDS analysis, project laboratory assistant Gülşen Albuz Geren (Ankara Hacı Bayram Veli University Historical Material Research and Conservation Laboratory-MAKLAB) for sample preparations.

Hakem Değerlendirmesi: Dış bağımsız.

Çıkar Çatışması: Yazar çıkar çatışması bildirmemiştir.

Finansal Destek: Bu çalışma, 34068 Proje numarası ile İstanbul Üniversitesi Bilimsel Araştırma Projeleri Koordinasyon Birimi tarafından finanse edilmiştir.

Teşekkür: Yazarlar, İstanbul Üniversitesi Bilimsel Araştırma Projeleri Birimi’ne, Prof. Dr. Sait Başaran’a, XRF ve Raman analizleri için Prof. Dr. Yusuf Kağan Kadıŏlu ve Dr. Öğretim Üyesi Kıymet Deniz (Ankara Üniversitesi, Yer Bilimleri Uygulama ve Araştırma Merkezi (YEBİM))'e, SEM-EDS analizleri için Emine Torgan Güzel (Türk Kültür Vakfi, Kültürel Miras ve Doğal Boya Laboratuvarı)'e ve örneklerin hazırlanması için proje laboratuvar asistanı Gülşen Albuz Geren (Hacı Bayram Veli Üniversitesi, Tarihi Malzeme Araştırma ve Koruma Laboratuvarı (MAKLAB))'e teşekkürü bir borç bilirler.

\section{References/Kaynakça}

Abd-Alla, Ramadan. "Devitrification Behaviour of Corroded Glass: Four Cases Study." Mediterranean Archaeology and Archaeometry 7/1 (2007): 39-49.

Akyol, Ali Akın and Yusuf Kağan Kadığlu. "Tekfur Sarayı Cam Buluntuları Arkeometrik Çalışmaları.” Türkiye Bilimler Akademisi Kültür Envanteri Dergisi 13 (2015): 27-36.

Akyol, Ali Akın, Şahinde Demirci, Yusuf Kağan Kadığlu, and Üzlifat Özgümüş. "İstanbul Yeni Cami Hünkar Kasrı Camları Üzerine Arkeometrik Çalışmalar.” II. ODTÜ Arkeometri ÇalıştaytTürkiye Arkeolojisi'nde Cam: Arkeolojik ve Arkeometrik Çalışmalar Bildiri Kitabı (6-8 Ekim 2011). Ankara: ODTÜ Yayınc1lık, 2012, 159-171.

Akyol, Ali Akın, Yusuf Kağan Kadığlu and Şahinde Demirci. “Arkeometrik Çalışmaların Işığında Elaiussa Sebaste Kazısı Camlarının (2002-2011) Karakterizasyonu.” Kaunos/Kbid Toplantıları 2: Anadolu Antik Cam Araştırmaları Sempozyumu (17-20 Haziran 2010). Ankara: Bilgin Kültür Sanat Yayınları, 2013, 197-212.

Akyol, Ali Akın, Yusuf Kağan Kadığlu, Üzlifat Özgümüş and Serra Kanyak. "İstanbul Koca Ragıb Paşa Kütüphanesi Camları Arkeometrik Analizleri.” Journal of Turkish Studies 9/10 (2014): 5-17.

Artioli, Gilberto. Scientific Methods and Cultural Heritage. New York: Oxford University Press, 2010.

Aydın, Mahmut, Ali Akın Akyol, Emel Erten and Emine Torgan. "Olba Kazısı Camları Arkeometrik Çalışmaları.” Seleucia 5 (2015): 197-220.

Bakırer, Ömür. “Cam Buluntuların Değerlendirilmesinde Arkeometrik Araştırmaların Önemi.” I. Arkeometri Toplantısı Bildiriler Kitabı. Ankara: Kültür Bakanlığı Yayınları, 1985, 61-67.

Başaran, Sait. “Ortaçağ’da Enez (Ainos).” Sanat Tarihi Dergisi IX (1998): 1-12.

Başaran, Sait. "Enez (Ainos) Kazıları.” Türkiye Arkeolojisi ve İstanbul Üniversitesi (1932-1999).

Ed. Oktay Belli. Ankara: İstanbul Üniversitesi Yayınları, 2000, 251-260. 
Başaran, Sait. "Enez, Ainos, Enoz.” Enez: Doğal, Kültürel ve Turistik Güzellikleri. Ed. A. Yeşil, A. Uzun, G.A. Aksu. İstanbul: Anadolu Ofset, 2013, 11-90.

Başaran, Sait, F. Banu Uçar Çakan, Gülder Emre, Gülnur Kurap, Stefan Karwiese and Ramazan Yılmaz. "Enez (Ainos) 2008 Yı1ı Kazısı, Onarım-Koruma Çalışmaları.” 31. Kazı Sonuçları Toplantıs1 (Denizli, 25-29 Mayıs 2009). Vol 2. Ankara: Kültür Bakanlığı Yayınları, 2010, 117 144.

Başaran, Sait and Gülnur Kurap. "Enez (Ainos) 2011 Yılı Arkeoloji Kazısı.” 34. Kazı Sonuçları Toplantısı (Çorum, 28 Mayıs-1 Haziran 2012). Vol 2. Ankara: Kültür Bakanlığı Yayınları, 2013, 375-378.

Başaran, Sait and Gülnur Kurap. "Enez (Ainos) 2012 Yılı Kazı Çalışmaları ile İlgili Rapor.” 35. Kazı Sonuçları Toplantısı (Muğla, 27-31 Mayıs 2013). Vol 3. Ankara: Kültür Bakanlığı Yayınları, 2014, 249-261.

Baykan, Ceren. Toprak Altı Cam Buluntuların Koruma ve Onarımı. İstanbul: Homer Kitabevi, 2014.

Baykan, Ceren and Daniş Baykan. Eskiçă̆'da Cam. İstanbul: Türk Eskiçağ Bilimleri Enstitüsü Yayınlar1, 2012.

Brill, Robert H. "Scientific Investigations of the Jalame Glass and Related Finds." Excavations at Jalame: Site of a Glass Factory in late Roman Palestine, 1988, 257-294.

Caner-Saltık, Emine N. “Arkeometrik Çalışmalar Işı̆̆ında Belirlenen Cam Bozulmaları.” II. ODTÜ Arkeometri Çalıştayı. Türkiye Arkeolojisi'nde Cam: Arkeolojik ve Arkeometrik Çalışmalar Kitabı (6-8 Ekim 2011). Ankara: ODTÜ Yayınları, 2012, 57-66.

Colomban, Philippe. "Case Study: Glasses, Glazes and Ceramics- Recognition of Ancient Technology from the Raman Spectra." Raman Spectroscopy in Archaeology and Art History. Ed. Howell G.M. Edwards and John M. Chalmers. Cambridge: Royal Society of Chemistry, 2005, 192-206.

Costagliola, Pilario, G. Baldi, Curzio Cipriani, Elena Pecchioni and Antonella Buccianti. "Mineralogical and Chemical Characterisation of the Medicean Glass Mosaic Tesserae and Mortars of the Grotta del Buontalenti, Giardino di Boboli, Florence, Italy." Journal of Cultural Heritage 1 (2000): 287-299.

Cox, G.A. and B.A. Ford. "The Long-Term Corrosion of Glass by Ground-Water." Journal of Materials Science 28 (1993): 5637-5647.

Davison, Sandra. Conservation and Restoration of Glass. London: Butterworths, 2006.

Doménech-Carbo, Maria-Teresa, Antonio Doménech-Carbo, Laura Osete-Cortina and MariaCarmen Saurí-Peris. "A study on Corrosion Processes of Archaeological Glass from the Valencian Region (Spain) and Its Consolidation Treatment." Microchimica Acta 154/1-2 (2006): 123-142.

Erzen, Afif. “Enez Kazıları.” XI. Türk Tarih Kongresi’nden Ayrıbasım. Ankara: Türk Tarih Kurumu, 1994, 301-307.

Freestone, Ian C., Matthew Ponting and Michael J. Hughes. "The Origin of Byzantine Glass from Maroni Petrera, Cyprus." Archaeometry 44/2 (2002): 257-272.

Freestone, Ian C., K. A. Leslie, Matthew Thirlwall and Yael Gorin-Rosen. "Strontium Isotopes in the Investigation of Early Glass Production: Byzantine and Early Islamic Glass from the Near East." Archaeometry 45/1 (2003): 19-32.

Gratuze, Bernard, Inès Pactat and Nadine Schibille. "Changes in the Signature of Cobalt Colorants in Late Antique and Early Islamic Glass Production.” Minerals 8/6 (2008): 1-20. 
Gueli, Anna M., Stefania Pasquale, Davide Tanasi, Stephan Hassam, Quentin Lemasson, Brice Moignard, Claire Pacheco, Laurent Pichon, Giuseppe Stella and Giuseppe Politi. "Weathering and Deterioration of Archeological Glasses from Late Roman Sicily." International Journal of Applied Glass Scence 11 (2020): 215-225.

Hasdemir, İlhan. “Arkeolojik Camların Kimyasına Göre Üretim Yerinin Tespitinde En Son Yöntem; Nadir Element Analizi Yöntemi." A paper presented at the 'III. Tarihi Eserleri Koruma: Cam Eserler Çalıştayı'. Muğla Sualtı Arkeoloji Enstitüsü, 12-14 October 2016.

Hasdemir, İlhan, Simon Striepe, Joachim Deubener, and Burkhard C. Schmidt. "Micromechanical Properties of Banded Alterations of Archaeological Glass Fragments." Journal of Non-Crystalline Solids 376 (2013): 126-132.

Henderson, Julian. Ancient Glass: An Interdisciplinary Exploration. New York: Cambridge University Press, 2013.

Huisman, Dirk Johannes, S. Pols, Ineke Joosten, Bertil J.H. van Os and A. Smit. "Degradation Processes in Roman Glass: Cases from the Bocholtz Burial." Journal of Archaeological Science 35/2 (2008): 398-411.

Kadikova, Irina F., Ekaterina. A. Morozova, Tatyana V. Yuryeva and Irina A. Grigorieva. "Study of Deteriorating Turquoise Lead-Potassium Glass Beads at Different Stages of Corrosion Using Micro-FTIR Spectroscopy.” Submitted to Materials Today: Proceedings, 2017, 1-7.

Koob, Stephen P. Conservation and Care of Glass Objects. New York: Archetype Publications, 2006.

Mäder, Michael, Dieter Grambole, Folker Herrmann, Christian Neelmeijer, Manfred Schreiner and Gebhard Woisetschläger. "Non-destructive Evaluation of Glass Corrosion States." Nuclear Instruments and Methods in Physics Research Section B: Beam Interactions with Materials and Atoms 136 (1998): 863-868.

Ohno, Yoshi. "Spectral Colour Measurement." Colorimetry: Understanding the CIE System. Ed. Janos Schanda. Chapter 5. New York: Wiley Publication, 2007, 101-132.

Palomar, Teresa. "Characterization of the Alteration Processes of Historical Glasses on the Seabed." Materials Chemistry and Physics 214 (2018): 391-401.

Palomar, Teresa, Jadra Mosa and Mario Aparicio. "Hydrolytic Resistance of $\mathrm{K}_{2} \mathrm{O}-\mathrm{PbO}-\mathrm{SiO}_{2}$ Glasses in Aqueous and High-Humidity Environments." Journal of the American Ceramic Society 103/9 (2020): 5248-5258.

Römich, Hannelore. "Glass and Ceramics.” Conservation Science: Heritage Materials. Ed. Eric May and Mark Jones. Cambridge: Royal Society of Chemistry, 2006, 160- 184.

Scott, Rebecca B. and Patrick Degryse. "The Archaeology and Archaeometry of Natron Glass Making." Glass Making in the Greco-Roman World: Results of the ARCHGLASS Project. Chapter 1. 2014, 15-26.

Shackley, M. Steven. "An Introduction to X-Ray Fluorescence (XRF) Analysis in Archaeology." $X$-Ray Fluorescence Spectrometry (XRF) in Geoarchaeology. Ed. Michael S. Shackley. New York: Springer Publication, 2011, 7-44.

Silvestri, Alberta, Gianmario Molin and Gabriella Salviulo. “Archaeological Glass Alteration Products in Marine and Land-Based Environments: Morphological, Chemical and Microtextural Characterization.” Journal of Non-Crystalline Solids 351 (2005): 1338-1349.

Silvestri, Alberta, Gianmario Molin and Gabriella Salviulo. "The colourless glass of Iulia Felix." Journal of Archaeological Science 35 (2008): 331-341. 
Verney-Carron, Aurélie, Loryelle Sessegolo, Mandana Saheb, Nathalie Valle, Patrick Ausset, Rémi Losno, Denis Mangin, Tiziana Lombardo, Anne Chabas and Claudine Loisel. "Understanding the Mechanisms of Si-K-Ca Glass Alteration Using Silicon Isotopes." Geochimica et Cosmochimica Acta 203 (2017): 404-421.

Watkinson, David, L. Weber and Kilian Anheuser. "Staining of Archaeological Glass from Manganese-Rich Environments." Archaeometry 47/1 (2005): 69-82.

Wedepohl, K. Hans and Albrecht Baumann. "The Use of Marine Molluskan Shells for Roman Glass and Local Raw Glass Production in the Eifel Area (Western Germany)." Naturwissenschaften 87/3 (2000): 129-132. 